\title{
Trace fossils and depositional environments of the middle Turonian sandstones in the Upper Nysa Kłodzka Graben (Sudetes, Poland) revisited
}

\author{
Alina CHRZĄSTEK ${ }^{1, *}$ and Nadia NOWICKA ${ }^{2}$ \\ 1 University of Wrocław, Institute of Geological Sciences, Maksa Borna 9, 50-204 Wrocław, Poland \\ 2 University of Wrocław, Plac Uniwersytecki 1, 50-137 Wrocław, Poland
}

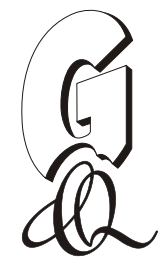

Chrząstek, A., Nowicka, N., 2021. Trace fossils and depositional environments of the middle Turonian sandstones in the Upper Nysa Kłodzka Graben (Sudetes, Poland) revisited. Geological Quarterly, 65: 10, doi: 10.7306/gq.1578

Associate Editor: Michał Zatoń

\begin{abstract}
We provide the first reports of some rare trace fossils from the middle Turonian (Upper Cretaceous) of the Sudety Mountains (SW Poland, Upper Nysa Kłodzka Graben, Długopole Górne Quarry). These include burrows ?Ancorichnus isp., Asterosoma cf. ludwigae Schlirf, 2000, Asterosoma isp., cf. Phycodes isp., Dactyloidites ottoi (Geinitz, 1849), Funalichnus strangulatus (Fritsch, 1883), Phycodes cf. palmatus (Hall, 1852), cf. Phycodes isp., Phycosiphon incertum Fischer-Ooster, 1858, ?Phycosiphon isp., Planolites beverleyensis (Billings, 1862) and borings Entobia isp. Some body fossils, bivalves ?Brachidontes sp., Lima canalifera Goldfuss, 1836, Pinna (Pinna) cretacea (Schlotheim, 1813) and Rhynchostreon suborbiculatum (Lamarck, 1801) are also reported. The trace fossil assemblage indicates a distal Skolithos ichnofacies and proximal Cruziana ichnofacies, which characterize a proximal and distal lower shoreface setting respectively. Sedimentation of the middle Turonian sandstones took place in a shallow epicontinental sea of normal salinity and a soft substrate, which was well-oxygenated under low-moderate hydrodynamic conditions. The presence of the oyster Rhynchostreon in the deposits studied suggests the influence of a warm Tethys Ocean.
\end{abstract}

Key words: ichnology, trace fossils, Upper Cretaceous, Sudetes, palaeoenvironment, shoreface.

\section{INTRODUCTION}

Middle Turonian sandstones are exposed in the western part of the Upper Nysa Kłodzka Graben, in the vicinity of the Długopole Górne (Długopole-Zdrój Syncline, see Don and Gotowała, 2008; Figs. 1-3). The Upper Nysa Kłodzka Graben is one of the Late Cretaceous basins, together with the Saxonian, Danubian (Bavaria), Bohemian, Intra-Sudetic and North Sudetic basins in Central Europe, located around the Mid-European Island, which separates the temperate Boreal Realm in the north from the warm Tethyan Province in the south (Janetschke et al., 2015; Niebuhr and Seibertz, 2018; Fig. 1). Sedimentation, in these closely connected marginal basins of the shelf sea, commenced during the Cenomanian and continued up to Coniacian or Santonian (cf. Voigt et al., 2008; Niebuhr and Seibertz, 2018 and references therein).

The Upper Nysa Kłodzka Graben is one of the youngest units in the Sudetes, Poland, which originated in the late Turonian-early Coniacian (see Wojewoda, 1997). The sandstones studied belong to so-called Quadersandstein

\footnotetext{
* Corresponding author, e-mail: alina.chrzastek@uwr.edu.pl
}

Received: August 11, 2020; accepted: November 30, 2020; first published online: March 15, 2021 megafacies (see Chrząstek, 2013a and references therein). Generalized sedimentological and tectonic data on sandstones from Długopole Górne Quarry were reported by Don and Wojewoda (2004), and trace fossils by Chrząstek (2013a). Sedimentological and ichnological data and interpretations of the correlative Radków Sandstones in the Intra-Sudetic Synclinorium were given by Jerzykiewicz and Wojewoda (1986), Wojewoda (1997) and Rotnicka (2005).

The newly found trace fossils (11 ichnogenera, 21 ichnospecies; 8 previously unknown from the study area), include the burrows ?Ancorichnus isp., Asterosoma cf. ludwigae Schlirf, 2000, Asterosoma isp., Dactyloidites ottoi (Geintz, 1849), Funalichnus strangulatus (Fritsch, 1883), Phycodes cf. palmatus (Hall, 1852), cf. Phycodes isp., Phycosiphon incertum Fischer-Ooster, 1858, ?Phycosiphon isp., Planolites beverleyensis (Billings, 1862) and borings Entobia isp. help infer the conditions of deposition of these sandstones. Moreover, Curvolithus simplex Buatois, Mángano, Mikuláš and Maples, 1998, Ophiomorpha nodosa Lundgren, 1891, Thalassinoides paradoxicus Kennedy, 1967, Thalassinoides suevicus (Rieth, 1932) and ?Thalassinoides isp., known earlier from the study area, have been also recorded (Table 1). A large swollen chamber (turn around, $21 \mathrm{~cm}$ in length) of an ophiomorid (Thalassinoides) has been also found.

Additionally, the body fossils ?Brachidontes sp., Pinna (Pinna) cretacea (Schlotheim, 1813) and Rhynchostreon suborbiculatum (Lamarck, 1801) provide new palaeo- 


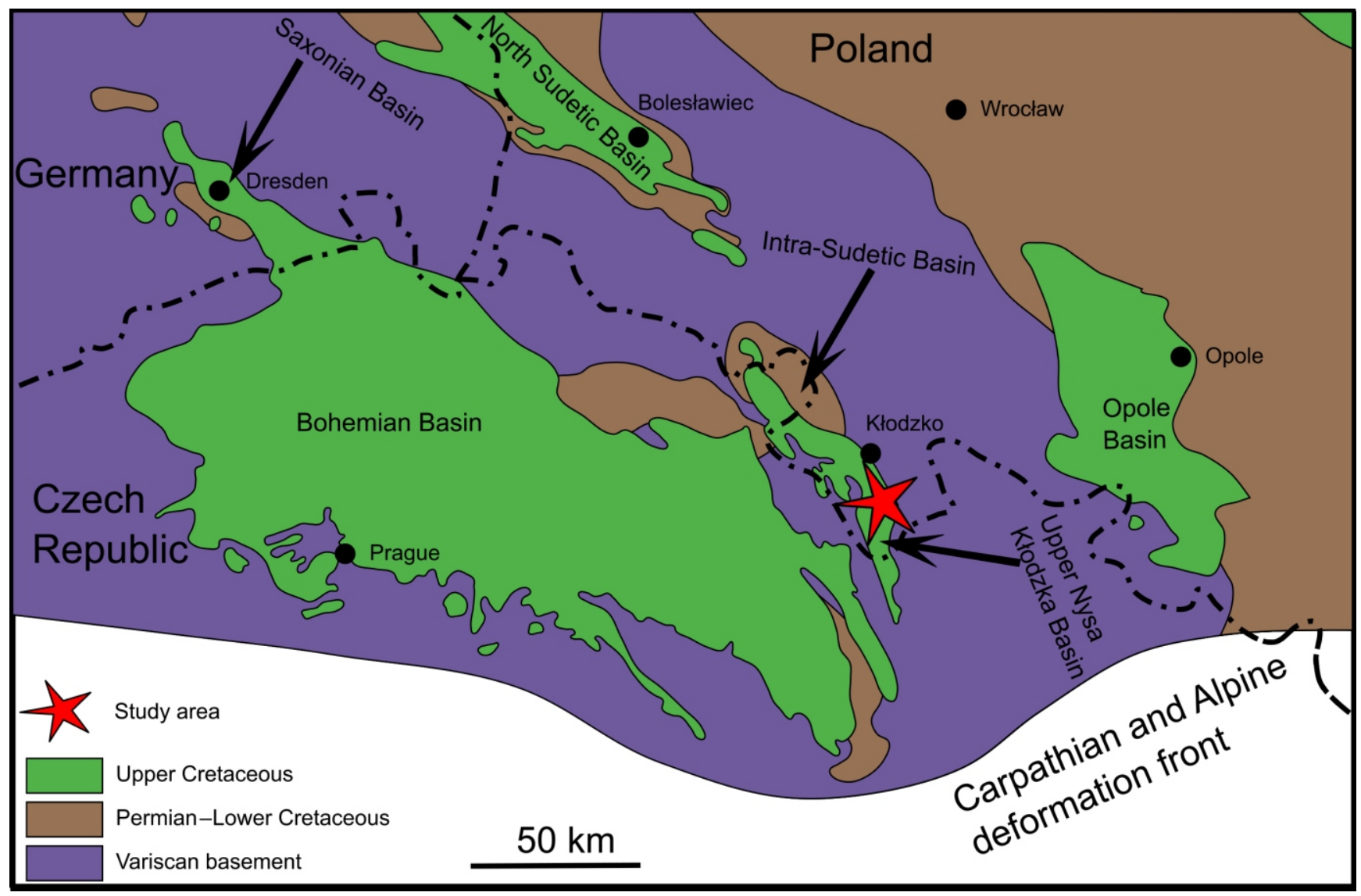

Fig. 1. Palaeogeographic map of the Sudetes region showing location of the Upper Cretaceous basins (according to Niebuhr and Seibertz, 2018; slightly modified by the authors)

nvironmental and palaeogeographical data. Dactyloidites and Funalichnus, rare trace fossils, are previously unknown from the Upper Cretaceous of the Upper Nysa Kłodzka Graben. These ichnotaxa were described from equivalent deposits of adjacent areas (Czech Republic and Germany) by Pokorný (2008), Pokorný and Bažant (2011), Wilmsen and Niebuhr (2014a) and Niebuhr and Wilmsen (2016). The other ichnospecies, Funalichnus bhubani Tiwari, Rajkonwar, Patel, 2013 has been reported from the lower-middle Miocene of India by Tiwari et al. (2013). These trace fossils are good palaeonvironmental indicators due to their restricted environmental ranges (see Uchman and Pervesler, 2007; Wilmsen and Niebuhr, 2014a). Other newly found trace fossils, such as ?Ancorichnus isp. (a very rare form, see Uchman and Krenmayr, 2004), Asterosoma cf. ludwigae, Asterosoma isp., Phycodes cf. palmatus, cf. Phycodes isp., Phycosiphon incertum, ?Phycosiphon isp. and Planolites beverleyensis, as well as accompanying body fossils, also provide new information on palaeonvironmental conditions during sedimentation of the middleTuronian sandstones. Asterosoma and Dactyloidites have been recently recorded in the Upper Nysa Kłodzka Graben from the late Coniacian (Idzików Quarry; Chrząstek, 2020), and Planolites from middle Turonian limestones (Stara Bystrzyca Quarry; Chrząstek, 2012). Other trace fossils reported here, e.g., ?Ancorichnus isp., Funalichnus strangulatus, Phycodes cf. palmatus, Phycosiphon incertum and borings Entobia isp. have not been previously described from the Upper Nysa Kłodzka Basin.
This paper describes the trace fossils collected so far, especially the previously unknown taxa (8 new ichnogenera). Palaeoecological study of the associated body fossils (bivalves) are also used in palaeoenvironmental analysis. Additionally, the trace and body fossil assemblage from the Upper Nysa Kłodzka Graben is compared, in ichnotaxonomical composition with other Upper Cretaceous assemblages from adjacent basins, e.g. the Saxony Cretaceous Basin (Elbe Group, Germany), Danubian Cretaceous Group (Bavaria, Germany), Bohemian Cretaceous Basin (Czech Republic) and North Sudetic and Intra-Sudetic basins (Poland; Fig. 1). Some sedimentologic and palaeogeographic conclusions are also drawn, e.g., the style of deposition of the succession studied and faunal interchanges between the North Temperate Realm and Tethyan Realm at the beginning of the middle Turonian.

\section{GEOLOGICAL SETTING}

The study was conducted in Długopole Górne Quarry, in which middle Turonian sandstones are exposed (Figs. 2 and 3 ). The Upper Cretaceous deposits of the Upper Nysa Kłodzka Graben are composed of detrital deposits: siliceous-calcareous mudstones, calcareous mudstones, sandstones, sandy limestones and spongiolites (Wojewoda, 1997; Don and Wojewoda, 2005; Don and Gotowała, 2008), up to $1200 \mathrm{~m}$ in thickness. In the Cenomanian, and middle and upper Turonian, the Quadersandstein megafacies appears (see Chrząstek, 2013a). 


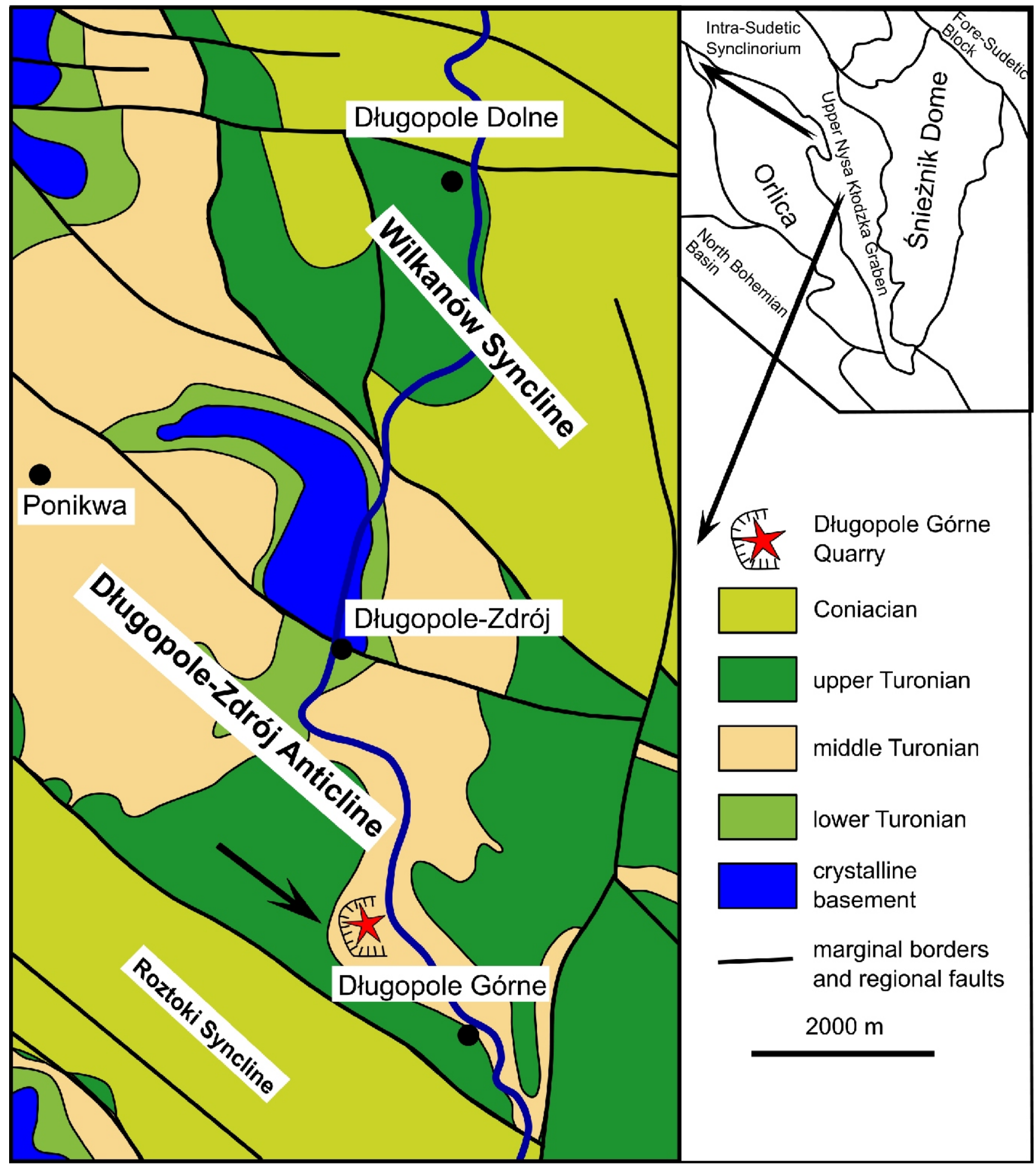

Fig. 2. Part of the geological map of the Upper Nysa Kłodzka Graben in the vicinity of Długopole Górne Quarry (after Don and Gotowała, 2008) and sketch of the Upper Nysa Kłodzka Graben (after Cymerman, 1997; slightly modified by the authors)

The middle Turonian sandstones are $45 \mathrm{~m}$ thick in the vicinity of Bystrzyca Kłodzka and reach 110 metres in the northern and northwestern parts of the Upper Nysa Kłodzka Graben (Don and Don, 1960; Fistek and Gierwielaniec, 1964; Komuda and Don, 1964; Radwański 1965, 1975; Wroński and Cwojdziński, 1984). The sandstones studied pinch out towards the south and the south-east (see Chrząstek, 2013a) and are $70 \mathrm{~m}$ thick in the neighbourhood of Długopole Górne (see also Wroński, 1982). The middle Turonian sandstones exposed in
Stara Bystrzyca and Długopole Górne Quarry represent the Inoceramus lamarcki Zone and probably represent the middle part of of the middle Turonian (cf. Chrząstek, 2013a and references therein). Niedźwiedzki and Salamon (2005), on the basis of the crinoid Bourgueticrinus sp., reported a late middle Turonian-earliest late Turonian age for the sandy siliceous mudstones, which were deposited in an offshore setting (see Chrząstek, 2012). 


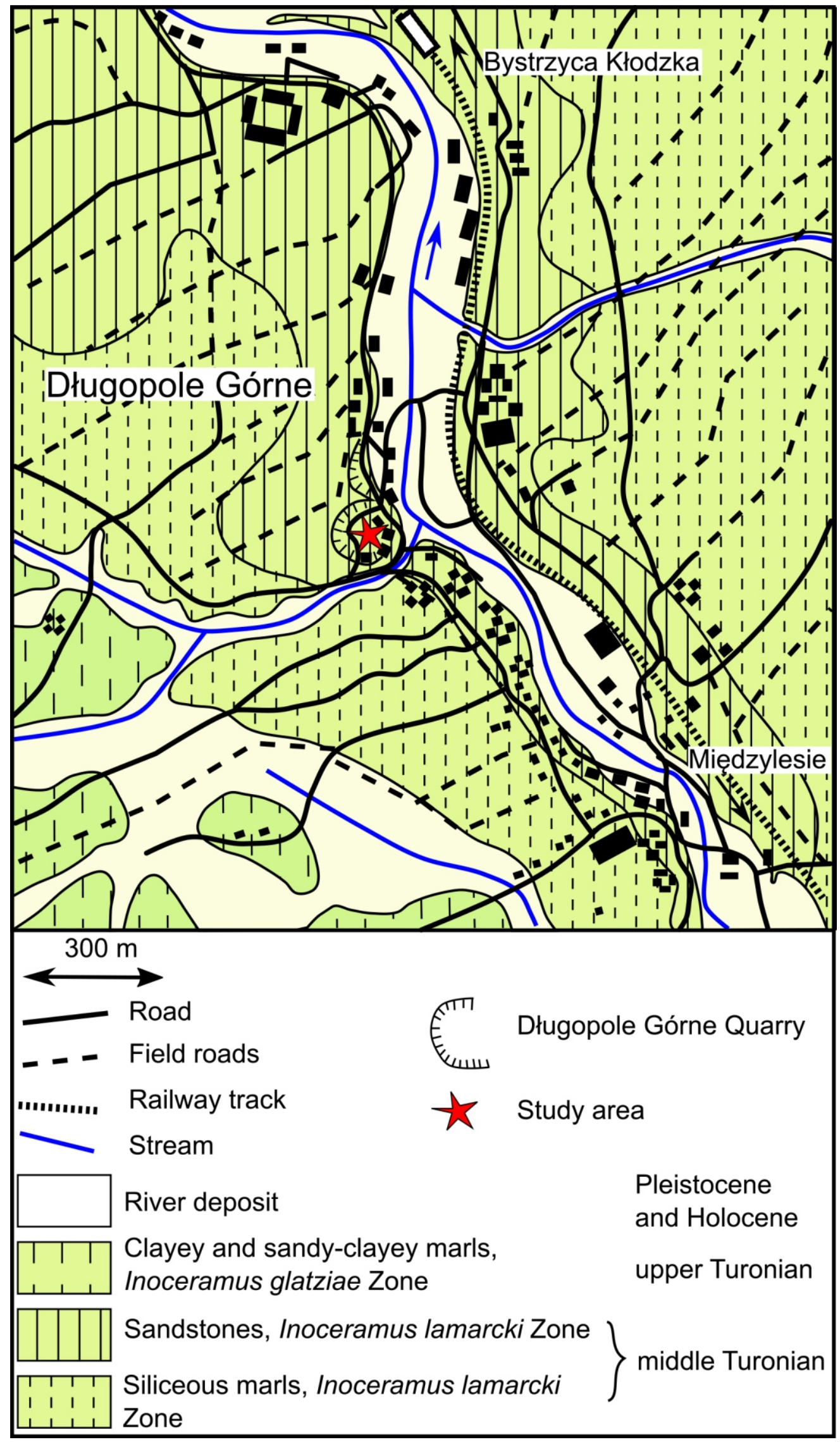

Fig. 3. Location sketch of the vicinity of Długopole Górne Quarry (according to Walczak-Augustyniak and Wroński, 1981) 
Table 1

Ichnodiversity and ichnoabundance of the trace fossils recorded in the middle Turonian sandstones in Długopole Górne Quarry

\begin{tabular}{|c|c|c|}
\hline & Ichnospecies & $\begin{array}{l}\text { Abundance: } \\
\text { abundant }++++ \\
\text { common }+++\end{array}$ \\
\hline 1 & ?Ancorichnus isp. & + \\
\hline 2 & Asterosoma cf. Iudwigae Schlirf, 2000 & + \\
\hline 3 & Asterosoma isp. & ++ \\
\hline 4 & cf. Asterosoma isp. & ++ \\
\hline 5 & Curvolithus simplex Buatois, Mángano, Mikuláš and Maples, 1998 & + \\
\hline 6 & Dactyloidites ottoi (Geinitz, 1849) & +++ \\
\hline 7 & Funalichnus strangulatus (Fritsch, 1883) & + \\
\hline 8 & ?Macaronichnus isp. (Chrząstek, 2013a) & + \\
\hline 9 & Ophiomorpha nodosa Lundgren, 1891 & ++++ \\
\hline 10 & Ophiomorpha isp. & +++ \\
\hline 11 & ?Ophiomorpha isp. & ++ \\
\hline 12 & Palaeophycus tubularis Hall, 1847 (Chrząstek, 2013a) & ++ \\
\hline 13 & Phycodes cf. palmatus (Hall, 1852) & + \\
\hline 14 & cf. Phycodes isp. & ++ \\
\hline 15 & Phycosiphon incertum Fischer-Ooster, 1858 & +++ \\
\hline 16 & ?Phycosiphon isp. & ++ \\
\hline 17 & Planolites beverleyensis (Billings, 1862) & + \\
\hline 18 & Thalassinoides paradoxicus Kennedy, 1967 & + \\
\hline 19 & Thalassinoides suevicus A (Rieth, 1932) & +++ \\
\hline 20 & Thalassinoides suevicus B (Rieth, 1932) & ++ \\
\hline 21 & Thalassinoides isp. & ++ \\
\hline 22 & ?Thalassinoides isp. & ++ \\
\hline 23 & Entobia isp. & ++ \\
\hline
\end{tabular}

The middle Turonian sandstones from the Upper Nysa Kłodzka Graben may be correlated in age, facies development and style of deposition with the Radków Bluff Sandstones of the Intra-Sudetic Basin (Stołowe Mountains; Wojewoda, 1997; Don and Gotowała, 2008; Fig. 3). The middle Turonian sandstones of the Intra-Sudetic Synclinorium (Stołowe Mountains) were interpreted by Jerzykiewicz and Wojewoda (1986) and Wojewoda (1997) as sandstone foresets (so-called accumulation terraces), up to $17 \mathrm{~m}$ thick, which show giant-scale cross-bedding. The equivalents of the middle Turonian sandstones in the Bohemian Cretaceous Basin (Jižera Formation) have been interpreted by various authors as sandstone bodies (subaquatic dunes) forming up to $14 \mathrm{~m}$ thick sets of "tabular cross-bedding", dominated by tidal and storm currents (cf. Skoček and Valečka, 1983) or deposits of a coarse-grained Gilbert-type delta (see discussion in Uličný, 2001; Laurin and Uličný, 2004). According to the latter authors, the fan-like shape of steep foreset packgaes, upward-coarsening trend and predominance of coarse-grained deposits may indicate deltaic sedimentation (cf. Uličný, 2001).

The depositional environment of the middle Turonian sandstones exposed in Długopole Górne Quarry (Figs. 2 and 3), has been interpreted as of shallow-marine, distal lower shoreface to upper offshore facies (Chrzastek, 2013a). The possible palaeonvironment for the equivalents of the studied deposits was suggested by Jerzykiewicz and Wojewoda (1986) and Rotnicka (2005) as offshore, ?upper offshore respectively.

In palaeogeographic terms, the middle Turonian sandstones are regarded as regressive deposits (Wojewoda, 1997). During the early middle Turonian, quiet pelitic sedimentation was interrupted by tectonic block movements that affected the source area and basin floor (East Sudetic Island; cf. Jerzykiewicz and Wojewoda, 1986; Wojewoda, 1997; Biernacka and Józefiak, 2009; Chrząstek and Wojewoda, 2011). Erosion in the source area produced large amounts of coarse clastic material, which was transported to the Upper Nysa Kłodzka Palaeobasin and deposited in elongated depressions, bordered by fault escarpments, forming giant foresets, i.e. accumulation terraces (cf. Jerzykiewicz and Wojewoda, 1986; Fig. 1). According to Voigt et al. (2008), in many Late Cretaceous European basins, long-term trends in relative sea-level changes (eustatic events) occurred, such as the late Cenomanian rise, the early Turonian peak and the middle Turonian low. A relative sea-level low was reached in the early middle Turonian (see also Rotnicka, 2005; Uličný et al., 2009), when sedimentation of the Długopole Górne sandstones began.

\section{MATERIAL AND METHODS}

Ichnological and sedimentological studies were carried out in Długopole Górne Quarry, PIASMAR Company (Szklary), and at the Arboretum Wojsławice (Branch of the Botanical Garden of the University of Wrocław).

Ichnological studies comprised ichnotaxonomy, ichnodiversity, ichnoabundance, ichnodisparity, bioturbation index (BI), and tiering pattern of the studied ichnoassemblage. Ichnodiversity refers to the number of ichnotaxa present, usu- 
ally at ichnogeneric level (see Luo et al., 2020), while ichnoabundance was measured after Knaust (2017, slightly modified): very rare (single specimens), rare (2-6 specimens), common (7-9 specimens), very common (10-22 specimens), abundant (>23; see Table 1). Ichnodisparity was assessed following Buatois and Mángano (2013) and Buatois et al. (2017) as the number of architectural designs. Bioturbation index (BI), which refers to the amount of bioturbation on bedding planes, was conducted after Taylor and Goldring (1993) and Taylor et al. (2003), redefined recently by MacEachern and Bann (2020, fig. 2), where $\mathrm{BI}=0$ means unbioturbated (bioturbation absent), $\mathrm{BI}=1$ sparse bioturbation $(1-5 \%), \mathrm{BI}=2$ uncommon bioturbation - low trace density (5-30\%), $\mathrm{BI}=3$ moderate bioturbation (30-60\%), $\mathrm{BI}=4$ common bioturbation $(60-90 \%)$, $\mathrm{BI}=5$ abundant bioturbation (90-99\%) and $\mathrm{BI}=6$ complete bioturbation (99-100\%). Bedding planes of the current-formed deposits, as well as crosscuts of sandstone blocks, parallel to bedding, $1.0 \mathrm{~m}$ long and $0.5 \mathrm{~m}$ high, were considered as reference levels for measuring the amount of bioturbation (bioturbation index). The tiering pattern of the studied trace fossils, understood here as distributions of burrows produced by benthic organisms above and beneath the sea floor (cf. Luo et al., 2020), was also described as shallow-, mid- and deep-tier (compare Rodríguez-Tovar et al., 2017). Tier 1 refers to surface trace fossils, shallow tier (tier 2) up to $15 \mathrm{~cm}$, mid tier (tier 3) from 15 to $50 \mathrm{~cm}$ and deep-tier (tier 4) more than $50 \mathrm{~cm}$ deep. Tiering patterns were studied in vertical cross-sections of the loose sandstone blocks, mainly at the the PIASMAR Company and in the Arboretum Wojsławice. The surfaces examined are $1.0 \mathrm{~m}$ in length and $1.0 \mathrm{~m}$ in high.

Ichnological analysis is based on the sedimentologicalichnological model for a wave-dominated shoreface (cf. Pemberton et al., 2012) redefined after MacEachern et al. (1999) and MacEachern and Bann (2008), in which the fair-weather wave base is located between the proximal and distal lower shoreface. The results of ichnological studies (ichnodiversity, ichnoabundance) are given in Table 1, while the distribution of the trace fossils recorded is shown in Figure 4. The sedimentological analysis were carried out on the middle Turonian sandstones in Długopole Górne Quarry, where the sedimentary structures, grain size distribution of the deposits and thickness of the individual beds were examined.

\section{THE MIDDLE TURONIAN SANDSTONES FROM DŁUGOPOLE GÓRNE QUARRY AND THEIR TRACE FOSSILS}

The middle Turonian deposits exposed in Długopole Górne Quarry are fine to coarse-grained sandstones. They show giant-scale cross-bedding $\left(210-230^{\circ}\right.$, see Don and Wojewoda, 2004: fig. 2) and represent the Quadersandstein megafacies (Chrząstek, 2013a). The individual beds are 0.5-3.0 m thick and lie almost horizontally (from $5-23^{\circ}$, see Don and Wojewoda, 2004). Some contain gravel intercalations. They are classified as quartzose-feldspathic sandstones (subarkosic arenite and quartz arenite, cf. Chrząstek, 2013a and references therein). The sedimentological structures, including paralle lamination, are poorly visible; these sandstones are mainly structureless. In the lower and middle part of the Długopole Górne section the sandstones are yellow-grey, while in the uppermost they are dark grey. They seem to show a coarsening-upward trend. Don and Wojewoda (2004) reported the trace fossil Ophiomorpha and the bivalve Exogyra columba (now Rhynchostreon; see Tröger, 2003) from these deposits. The bivalves cited, as well as pectenids, had been previously reported from the basal part of the middle Turonian sandstones by Fistek and Gierwielaniec (1964). The present author (Chrząstek, 2013a) described, from the middle Turonian sandstones of Długopole Górne Quarry, an assemblage of trace fossils comprising Ophiomorpha nodosa Lundgren, 1891, Ophiomorpha isp., Thalassinoides suevicus (Rieth, 1932), Thalassinoides cf. paradoxicus Kennedy, 1967, formerly $T$. paradoxicus (Woodward, 1830), Thalassinoides isp., Curvolithus simplex Buatois, Mángano, Mikuláš and Maples, 1998, Palaeophycus tubularis Hall, 1847, ?Macaronichnus isp., as well as the associated body fossil Lima canalifera Goldfuss, 1836. In the collection of the Geological Museum of the University of Wrocław there are also specimens of the bivalve Lima canalifera Goldfuss, 1836 (MGUWr-1499s) and rhynchonellids (MGUWr-1883s; cf. Chrząstek, 2013a) from this site.

The assemblage of trace and body fossils was studied mainly in the field in Długopole Górne Quarry. Moreover, studies were carried out also on loose sandstone blocks located at the PIASMAR Company (Szklary) and the Arboretum Wojsławice. Some specimens were collected and are now housed in the Geological Museum of the University of Wrocław, e.g., Dactyloidites ottoi, Funalichnus strangulatus, Ophiomorpha nodosa, Thalassinoides suevicus, Entobia isp., Lima canalifera and Pinna (Pinna) cretacea (MGUWr-6756s-6762s).

The trace fossils studied occur mainly in the walls of Długopole Górne Quarry (Asterosoma cf. ludwigae, Curvolithus simplex, Phycodes cf. palmatus, Ophiomorpha nodosa, Ophiomorpha isp., ?Ophiomorpha isp., Planolites beverleyensis, Thalassinoides suevicus, Thalassinoides isp., ?Thalassinoides isp.) or on extracted sandstone slabs (e.g., Funalichnus strangulatus). Asterosoma isp., cf. Asterosoma isp., Dactyloidites ottoi, cf. Phycodes isp., Phycosiphon incertum, ?Phycosiphon isp., Thalassinoides paradoxicus were found mainly in cross-sections of or on sandstone blocks collected at the PIASMAR Company in Szklary and in the Arboretum Wojsławice. Body fossils, bivalves e.g., ?Brachidontes sp., Lima canalifera, Pinna (Pinna) cretacea and Rhynchostreon suborbiculatum were found in situ in Długopole Górne Quarry and in extracted blocks gathered for further processing at the PIASMAR Company in Szklary.

In the lower part of the rock succession examined on the Długopole Górne walls, Thalassinoides suevicus type A (usually from 3,0 to $5.5 \mathrm{~cm}$ in diameter, max. $7 \mathrm{~cm}$ ) and type $B$ $(1.5-2.0 \mathrm{~cm})$ and Ophiomorpha nodosa prevail. Individual occurrences of Asterosoma cf. ludwigae, Curvolithus simplex and Planolites beverleyensis were recorded in the upper part of the Długopole Górne section, besides Ophiomorpha nodosa, ?Ophiomorpha isp., Thalassinoides suevicus B and ?Thalassinoides isp., which appear in abundance (Fig. 4 and Table 1). Moreover, in the uppermost part of the succession studied, Ophiomorpha nodosa, Phycodes cf. palmatus and a large swollen chamber of Thalassinoides with tunnels (up to $30 \mathrm{~cm}$ long) were recorded. In the middle part of the Długopole Górne section Ophiomorpha nodosa appears (mostly as vertical shafts) together with the bivalves ?Brachidontes sp., Lima canalifera, Pinna (Pinna) cretacea and Rhynchostreon suborbiculatum (Fig. 4).

\section{RESULTS}

\section{DESCRIPTION OF TRACE FOSSILS}

21 ichnospecies belonging to 11 ichnogenera (8 newly found) have been identified in total in the Długopole Górne Quarry section (Figs. 2-5A) and in extracted blocks of the sand- 


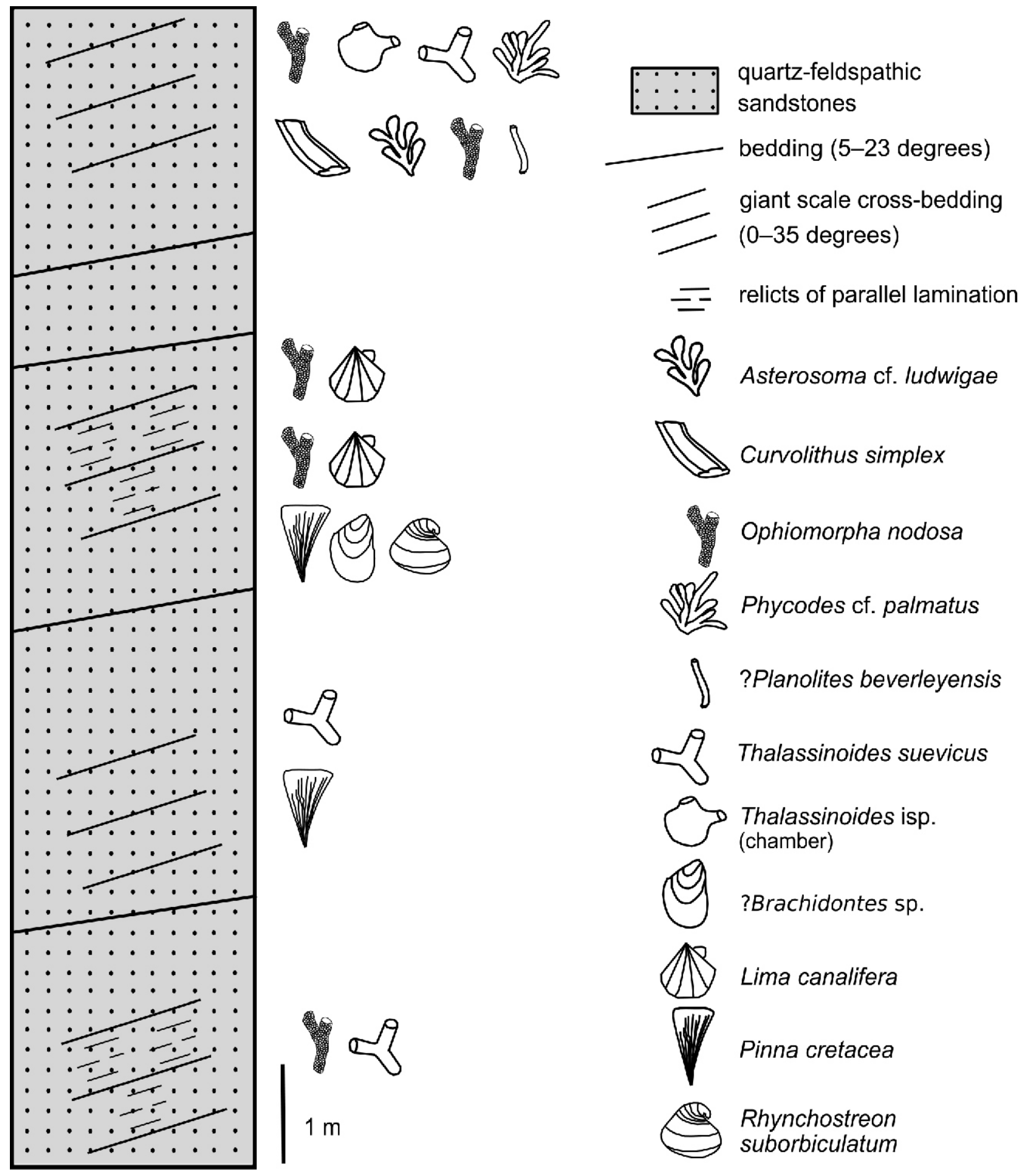

Fig. 4. Lithological log of the middle Turonian sandstones in Długopole Górne Quarry indicating distribution of trace fossils Bedding and giant scale cross-stratification according to Don and Wojewoda (2004)

stones located at the PIASMAR Company (Szklary) and in the Arboretum Wojsławice. The ichnogenera identified include ?Ancorichnus, Asterosoma, Curvolithus, Dactyloidites, Funalichnus, Ophiomorpha, Phycodes, Phycosiphon, Planolites and Thalassinoides. Moreover, the boring Entobia and some questionable burrows occur (Table 1). The distribution of individual trace fossils on the walls of Długopole Górne Quarry is shown in Figure 4, while the environmental distribution of the ichnotaxa identified is outlined in Figure 12. The ichnodiversity and ichnoabundance of the trace fossil assemblage studied is shown in Table 1. Five ichnogenera (Curvo- lithus, ?Macaronichnus, Ophiomorpha, Palaeophycus and Thalassinoides) have been reported by Chrząstek (2013a) from Długopole Górne Quarry.

BURROWS

Ancorichnus Heinberg, 1974

?Ancorichnus isp.

(Figs. 5B and 9C) 
M a t e r i a I. - One specimen preserved as a longitudinal cross-section (Figs. 5B, 9C; PIASMAR Company, Wojsławice), which co-occurs with Phycosiphon incertum.

D e s c ription. - Ancorichnus occurs as a cylindrical, horizontal, unbranched burrow parallel to the bedding plane. The burrow shows a meniscate backfill (inner fill, Fig. 5B), identical to the host rock and a structured tube-shaped mantle (outer fill). The burrow shows a weakly and irregularly winding course (Fig. 5B). The outer layer is slightly darker than the core (Fig. 5B). The total length of the structures is $15-30 \mathrm{~cm}$, and the width 2-6 cm. The external layer (mantle) is $0.6-1.6 \mathrm{~cm}$ wide.

$\mathrm{R}$ e $\mathrm{m}$ a r k s. - The burrow resembles Ancorichnus, which is characterized by a central (inner) meniscate filling and a structured, undulating mantle or tube-shaped outer fill (see Heinberg, 1974; Dam, 1990; Keighley and Pickerill, 1994; Desai and Saklani, 2014). According to the cited authors, the mantle is not considered as a wall structure since it was formed by the locomotive behavior of the burrow producer. The specimen studied does not differ significantly from the specimens described by Keighley and Pickerill (1994: text-figs. 1, 20), Uchman and Krenmayr (2004: fig. text-fig. 5) and Boyd and Mcllroy (2017: fig. 9). The presence of a mantle and lack of wall distinguishes Ancorichnus Heinberg, 1974 from Beaconites Vialov, 1962 (see Boyd and Mcllroy, 2017). Ancorichnus is in some ways similar to another ichnogenus, Taenidium Heer, 1877 , which also has no wall, but differs from it by having an outer mantle (cf. Keighley and Pickerill, 1994; Baucon and Neto de Carvalho, 2008). The specimens studied probably represent Ancorichnus ancorichnus, because the ichnogenus studied is described as monospecific (cf. Keighley and Pickerill, 1994).

Ancorichnus is regarded as a pascichnion (Fürsich et al., 2018) or a repichnion (Heinberg, 1974; Mángano and Buatois, 2016) or a repichnion/domichnion (Dam, 1990) produced by deposit-feeder worm-like animals, insect larvae or arthropods (Heinberg, 1974; Frey et al., 1984b; Patel et al., 2008). It characterizes the Cruziana ichnofacies (Baucon and Neto de Carvalho, 2008) and is typical of the shallow-marine (lower shoreface) to offshore setting (Frey and Howard, 1985; MacEachern et al., 1999; Desai and Saklani, 2014). It is known from the Jurassic to the present (Heinberg, 1974; Mángano and Buatois, 2016).

\section{Asterosoma von Otto, 1854}

Asterosoma cf. Iudwigae Schlirf, 2000

$$
\text { (Fig. 5C) }
$$

M a t e ri a I. - One specimen preserved as a full relief oblique section, visible in Figure 5C (Długopole Górne Quarry).

Description. - A cross-section of several bulbs (3-?6), showing concentric or irregular lamination, and a fragmentarily preserved cylindrical tunnel (axis) is visible on the sandstone surface. The study specimen is arranged horizontally along the bedding-plane and enlarged in one direction. The bulbs seem slightly narrower at their terminations. The length of the whole structure is $28-30 \mathrm{~cm}$, and its width $8 \mathrm{~cm}$. A fragmentarily preserved axis is $1.5 \mathrm{~cm}$ in width. The probable bulbs are up to $6 \mathrm{~cm}$ in width and $8 \mathrm{~cm}$ in length.

$\mathrm{R}$ e $\mathrm{m}$ a r k s. - The study specimen, which resembles the cross-section of a partially preserved cylindrical axis and several bulbs arranged in one direction, shows similarities to Asterosoma ludwigae Schlirf, 2000. It is similar to the speci- mens reported by Leszczyński (2010: fig. 14E; 2018: fig. 33C) from the Santonian of the North Sudetic Synclinorium and by Neto de Carvalho et al. (2010: fig. 4D) from the Jurassic of Portugal. It might resemble a third morphotype of Asterosoma (cf. Neto de Carvalho and Rodrigues, 2007: figs. 7F, H, 9) in which ramification tends to be more numerous in a single direction while burrow bundles (consisting usually of 4-6 bulbs) reach various lengths (up to $30 \mathrm{~cm}$ ).

Asterosoma is interpreted as a fodinichnia of detritus-, suspension- or selective deposit-feeders (Neto de Carvalho and Rodrigues, 2007; Knaust, 2017 and references therein). Crustaceans (crabs, lobster-like animals) and polychaetes are suggested as the potential trace makers (Häntzschel, 1975; Głuszek, 1998; Pemberton et al., 2001). This ichnogenus characterizes mainly the Cruziana ichnofacies (MacEachern et al., 2007, 2012), though can also appear in the Skolithos, Zoophycos and Nereites ichnofacies (Knaust, 2017). Asterosoma occurs from marginal-marine (paralic) to deep-marine environments, but it is especially common in shallow-marine settings (Bromley and Uchman, 2003; Rindsberg and Martin, 2003; Knaust, 2017 and references therein). It is most characteristic of the proximal lower shoreface (cf. Pemberton et al., 2001, Pervesler and Uchman, 2004). Its stratigraphical range is from the Cambrian (Mángano and Buatois, 2016) to the present (Häntzschel, 1975; Dashtgard et al., 2008).

\section{Asterosoma isp. \\ (Fig. 6A-C)}

$\mathrm{M}$ a t e r i a l. - A few specimens on sandstone block surfaces or as cross-sections (Wojsławice). Their features are unclear, while questionable forms, ?Asterosoma isp. and cf. Asterosoma isp., are also present (Fig. 6B and 6C from Szklary and Wojsławice, respectively). A cross-section is shown in Figure $6 \mathrm{~A}$.

D e s c ription. - Asterosoma appears as a complex trace fossil composed of a bunch of bulb-shaped structures and associated tubes (as a tree-like structure; Fig. 6B), $10 \mathrm{~cm}$ long and $12 \mathrm{~cm}$ wide. Cross-sections across the individual bulbs, which have preserved concentric internal structure, were also observed (Fig. 6A). These are up to $5 \mathrm{~cm}$ wide. One cross-section of a bulb with poorly preserved concentric structure was described as cf. Asterosoma isp. (Fig. 6C).

Remarks. - The specimens are most similar to Asterosoma in having tubes with bulbs, which show concentric laminae in the fill. They differ from the similar trace fossil Rosselia Dahmer, 1937, which occurs as a single bulb, in their lack of lining (cf. Hoffmann and Grimmberger, 2011).

Curvolithus Fritsch, 1908

Curvolithus simplex Buatois, Mángano, Mikuláš and Maples, 1998

$$
\text { (Fig. 6D) }
$$

$\mathrm{M}$ a t e r i a I. - One specimen preserved in positive relief on the upper surface of a sandstone bed, co-occurring with Asterosoma cf. ludwigae (Długopole Górne Quarry). The second specimen, described by Chrząstek (2013a: fig. 6A) is preserved as horizontal, epichnial structure. 

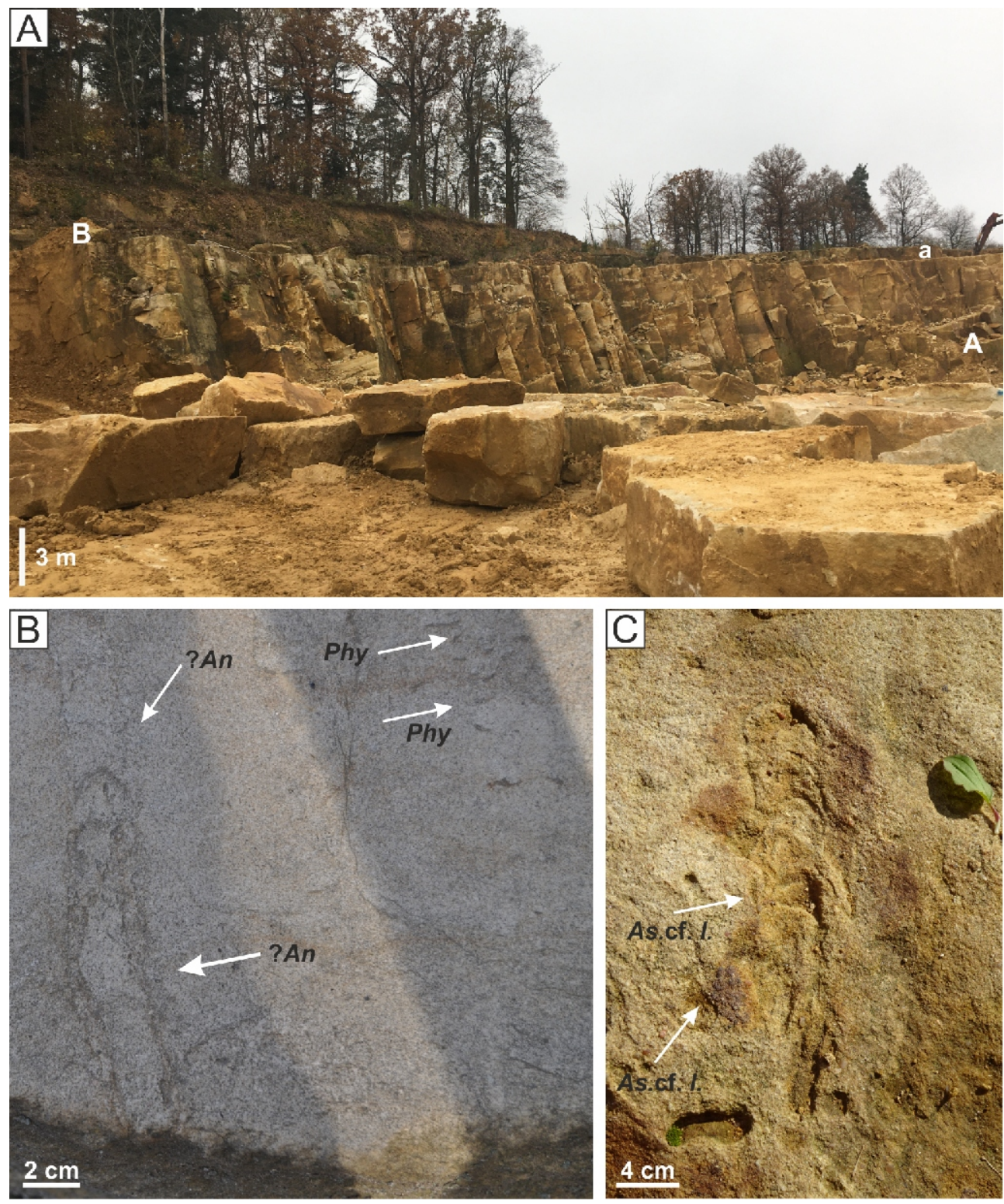

Fig. 5. Długopole Górne Quarry and trace fossils ?Ancorichnus isp., Asterosoma cf. ludwigae and Phycosiphon incertum

A - Middle Turonian sandstones from Długopole Górne Quarry, A - fine-medium grained sandstones, B - medium-coarse grained sandstones, a - the place where the Thalassinoides chamber was found; B ?Ancorichnus isp., Phycosiphon incertum (in longitudinal cross-section parallel to bedding), Wojsławice, loose block; C - Asterosoma cf. ludwigae on a bedding plane, longitudinal section, Długopole Górne Quarry (rock in situ), photograph - M. Stempień-Sałek; abbreviations: ?An - ?Ancorichnus isp., As cf. I.

- Asterosoma cf. ludwigae, Phy - Phycosiphon incertum

Description. - Curvolithus appears as an unbranched, horizontal, straight to meandering tongue-like structure. It is trilobate, consisting of three rounded lobes. A central lobe (up to $1.8 \mathrm{~cm}$ ) is wider than the lateral ones (each $0.6 \mathrm{~cm}$ ) and is separated from them by shallow furrows. It seems generally smooth. The visible length of this winding tunnel is $25 \mathrm{~cm}$. The specimen, described previously by Chrząstek (2013a), occurred as a flattish, slightly winding structure, $2 \mathrm{~cm}$ in width and $8 \mathrm{~cm}$ in length.

R e marks. - The study specimen is most smilar to Curvolithus, in having a trilobate, flattened shape (cf. Buatois et al., 2017). It shows also some silimilarities to the locomotion-feeding (pascichnia) traces of the echinoid Scolicia de
Quatrefages, 1849 (see Phillips et al., 2011: fig. 3E; López Cabrera and Olivero, 2014: fig. 2f; Carmona et al., 2020) in having two distinctive concave lobes which resemble parallel strings, most characteristic of this ichnogenus, as well as a flat to slightly concave-up area between them. However, it differs from Scolicia in lacking the typical laminated backfill. Curvolithus is a locomotion trace (repichnion) made by gastropods, polychaetes, nemerteans, holothurians or flatworms (Heinberg and Birkelund, 1984; Lockley et al., 1987; Seilacher, 2007). Curvolithus is typical of the Cruziana ichnofacies sensu Seilacher (1967) or Curvolithus subichnofacies sensu Lockley et al. (1987), corresponding to deltaic-influenced nearshore environments (cf. Baucon and Neto de Carvalho, 2008). It is com- 

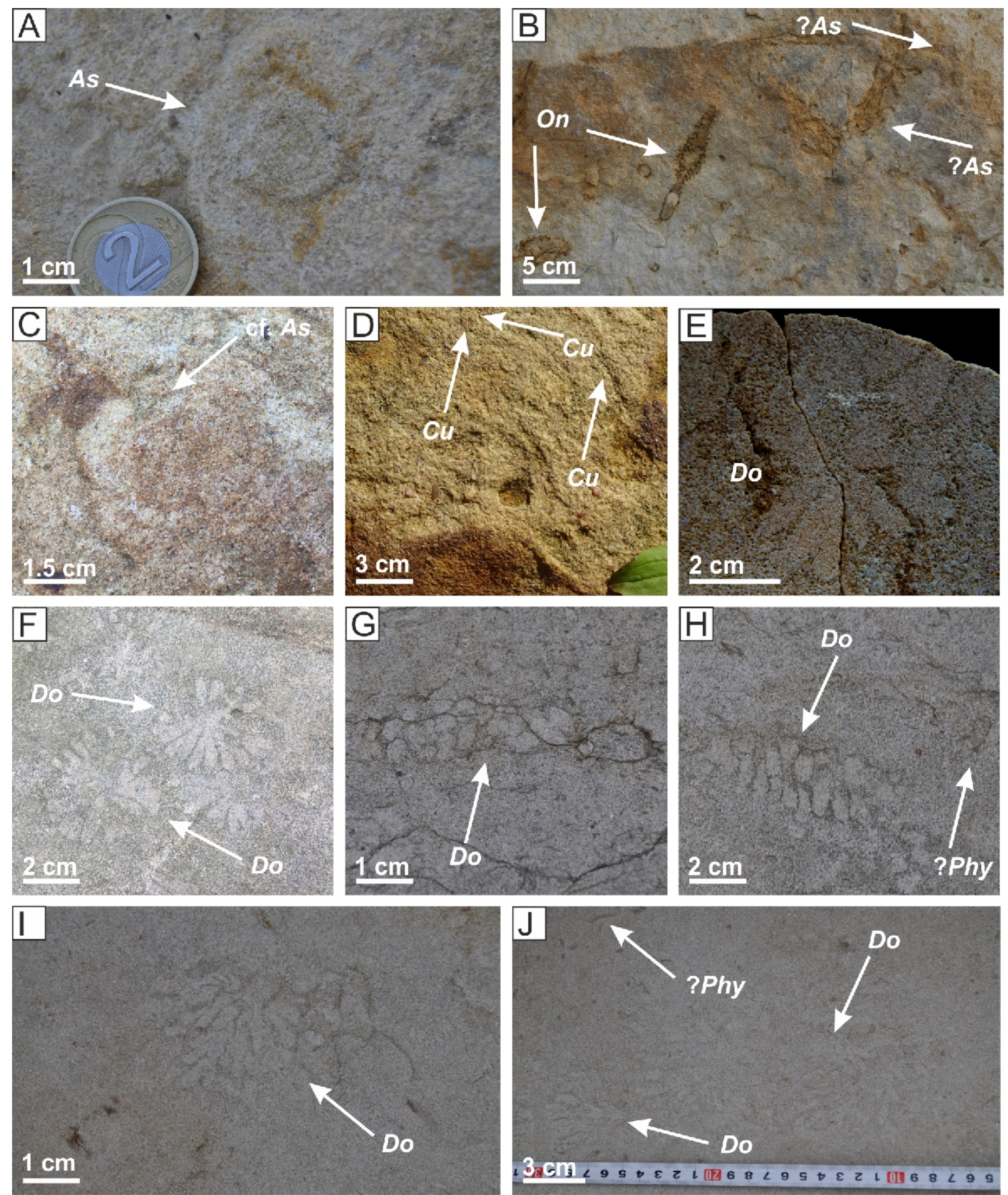

Fig. 6. Trace fossils from the middle Turonian sandstones

A - Asterosoma isp., Wojsławice (loose block, bedding plane); B - whole specimen of ?Asterosoma isp. and Ophiomorpha nodosa, Szklary (loose block, bedding plane); C - cf. Asterosoma isp., Wojsławice (loose block); D Curvolithus simplex on the upper part of a sandstone bed, Długopole Górne Quarry (rock in situ), photograph - M. Stempień-Sałek; E - Dactyloidites ottoi, Szklary (loose block, bedding plane); MGUWr-6756s; F - Dactyloidites ottoi, Wojsławice (loose blocks, bedding plane); G, H - Dactyloidites ottoi preserved in vertical cross-section, Wojsławice (loose blocks); I, J - Dactyloidites ottoi and ?Phycosiphon isp. preserved on a bedding-parallel surface, Szklary (loose block); abbreviations: As - Asterosoma isp., cf. As - cf. Asterosoma isp., Cu - Curvolithus simplex, Do - Dactyloidites ottoi, ?Phy - ?Phycosiphon isp., On - Ophiomorpha nodosa 
mon in shallow marine or marginal marine settings, up to the upper offshore zone (Maples and Suttner, 1990; Buatois et al. 1998). It is reported from the Ediacaran to Holocene interval (Lockley et al., 1987).

Dactyloidides Hall, 1886

Dactyloidides ottoi (Geinitz, 1849)

(Figs. 6E-J and 7A-E)

M a t e r i a I. - Several specimens preserved as shallowto mid-tier forms (in vertical section and on bedding planes), recorded in sandstone blocks found at PIASMAR Company (Szklary) and in the Arboretum Wojsławice (MGUWr-6756s). In some cases, they co-occur with ?Phycosiphon isp. (Fig. 6J).

De s c ription. - The specimens studied appear as several rosettes, palmate or fan-shaped spreite-like structures, originating from a central point. The radial elements (up to 20), which are of different length, form incomplete circular rosettes (from 210 up to $270^{\circ}$ ), $3.5-6.0 \mathrm{~cm}$ wide (Figs. 6E, F and 7A-C). The individual radial elements, which are subhorizontal protrusive vertical spreiten, are usually up to $0.6 \mathrm{~cm}$ in width and $2.0-2.5 \mathrm{~cm}$ in length. In some cases, some primary radial elements of individual rosettes, in their uppermost part, bifurcate (Figs. 6F and 7A). The secondary radial elements are $1.0 \mathrm{~cm}$ in length and $0.4 \mathrm{~cm}$ in width. Radial elements within individua structures were also observed in vertical or oblique sections relative to bedding, appearing as elliptical to circular structures, in some cases elongated in a vertical direction (Figs. 6G-J and 7D, E). They are arranged in up to four tiers (structures which touch each other).

$\mathrm{R}$ e $\mathrm{m}$ a r k s. - The presence of several rosette-like structures, which represent the uppermost tier, preserved in horizontal section and radial elements stacked together in up to a few tiers in vertical section, suggests assignment to Dactyloidites ottoi (cf. Fürsich and Bromley, 1985: figs. 1, 3, 4). Other ichnospecies of Dactyloidites, e.g., Dactyloidites asteroides (Fitch, 1850) differs in having a smaller number of ridges (4-6) in comparison to the study specimens. Dactyloidites peniculus Uchman and Pervesler, 2007 has pellets which distinguish it from other ichnospecies of Dactyloidites (see discussion in Uchman and Pervesler, 2007). Dactyloidites jordii Boyd and Mcllroy, 2016 also differs from the current ichnospecies in having an incomplete rosette and long, narrow rays while the component burrows can branch both horizontally and vertically. The study specimens show also some similarities to other radial to rosetted trace fossils (cf. Buatois et al., 2017) Gyrophyllites kwassizensis Glocker, 1841 and Gyrophyllites cristinae Muñoz, Mángano and Buatois, 2019 in having horizontal, swollen leaf-like lobes (radial elements), radiating from a central shaft (cf. Uchman, 1998). However, they differ from G. kwassizensis in their lack of slightly curved overlapping lobes and an outer convex arc which rim the individual rosettes (Strzeboński and Uchman, 2015: figs. 6D, 7A, B, 8F). These specimens also show some affinities to Gyrophyllites cristinae, which possess five to six petaloid non-overlapping, smooth and oval lobes (see Muñoz et al., 2019: figs. 4, 5A), but the main difference is the presence only one level of circular, unbranched lobes in the case of G. cristinae.

Dactyloidites ottoi is ethologically a fodinichnion (Fürsich and Bromley, 1985; Pickerill et al., 1993). The potential trace makers of Dactyloidites are worm-like organisms, producing a set of rosettes from the same central shaft in searching for food (Uchman and Pervesler, 2007; Wilmsen and Niebuhr, 2014a).
Crabs are also suggested as potential producers of Dactyloidites (Gibert et al., 1995). Dactyloidites is typical of the lower Skolithos and upper Cruziana ichnofacies (see Wilmsen and Niebuhr, 2014a). Dactyloidites ottoi occurs in shallow-water, nearshore to deltaic, nutrient-rich siliciclastic settings, usually between the fair-weather and storm wave bases, commonly at the top of shallowing-upwards cycles (Fürsich and Bromley, 1985; Agirrezabala and Gibert, 2004; Mayoral et al., 2013). Dactyloidites ottoi is a relatively rare form, known from the ?Triassic, Jurassic to Neogene (Wilmsen and Niebuhr, 2014a).

\section{Funalichnus Fritsch, 1883 \\ Funalichnus strangulatus (Fritsch, 1883)}

(Fig. 8A)

$\mathrm{M}$ a t e ri a I. - One specimen visible on the surface of a loose sandstone block, Długopole Górne Quarry (MGUWr-6757s).

D e s c r i p t i o n. - Straight, oblique, cylindrical, unlined and unbranched burrow, ornamented by closely spaced, distinct, swollen ribs, which are oriented slightly obliquely towards the longitudinal axis. The interspaces between the cylindrical ribs form curved depressions. The burrow fill is structureless. The burrow is circular to subcircular in cross-section. The diameter of the burrow ranges from $1.0-1.5 \mathrm{~cm}$. The visible length is $7.5 \mathrm{~cm}$.

$\mathrm{R}$ e $\mathrm{m}$ a $\mathrm{rk} \mathrm{s}$. - The specimen studied does not differ from similar burrows described by Pokorný (2008: figs. 4-6) and Pokorný and Bažant (2011), from the upper Turonian of the Czech Republic, in having closely spaced ribs, which are oriented obliquely to the axis of the burrow. The lower termination of the burrow, which is usually smooth and tapering, is not observed. The specimen differs from another ichnospecies, $F$. bhubanii Tiwari, Rajkonwar and Patel, 2013, especially in lacking perpendicular oriented segments to the axis (Tiwari et al., 2013).

Funalichnus probably represents a domichnion but this ethologic interpretation is still unclear (cf. Pokorný, 2008). Annelids are suggested as the possible trace makers. This ichnotaxon characterizes the Skolithos and Cruziana ichnofacies (Pokorný, 2008), occurring in deposits of a shallow-marine setting of moderate to high energy (foreshore-shoreface, see Tiwari et al., 2013; Rajkonwar et al., 2015). Funalichnus strangulatus occurs in the upper Cenomanian, as well as in the middle-upper Turonian of the Czech Republic (Bohemian Cretaceous Basin, see Pokorný, 2008) and Germany (Saxonian and Danubian basins, see Wilmsen and Niebuhr, 2014a; Niebuhr and Wilmsen, 2016). Tiwari et al. (2013) reported this ichnogenus from the lower-middle Miocene of India.

Ophiomorpha Lundgren, 1891

Ophiomorpha nodosa Lundgren, 1891

(Figs. 8A-M and 9D, 10F)

M a t e r i a I. - Several specimens preserved on the sandstone walls of the Długopole Górne Quarry (MGUWr-6758s), as well as in blocks and in the cross-sections (Szklary, Wojsławice), earlier described by Chrząstek (2013a: figs. $6 B-F, 7 A-D)$ from the current sandstones. 

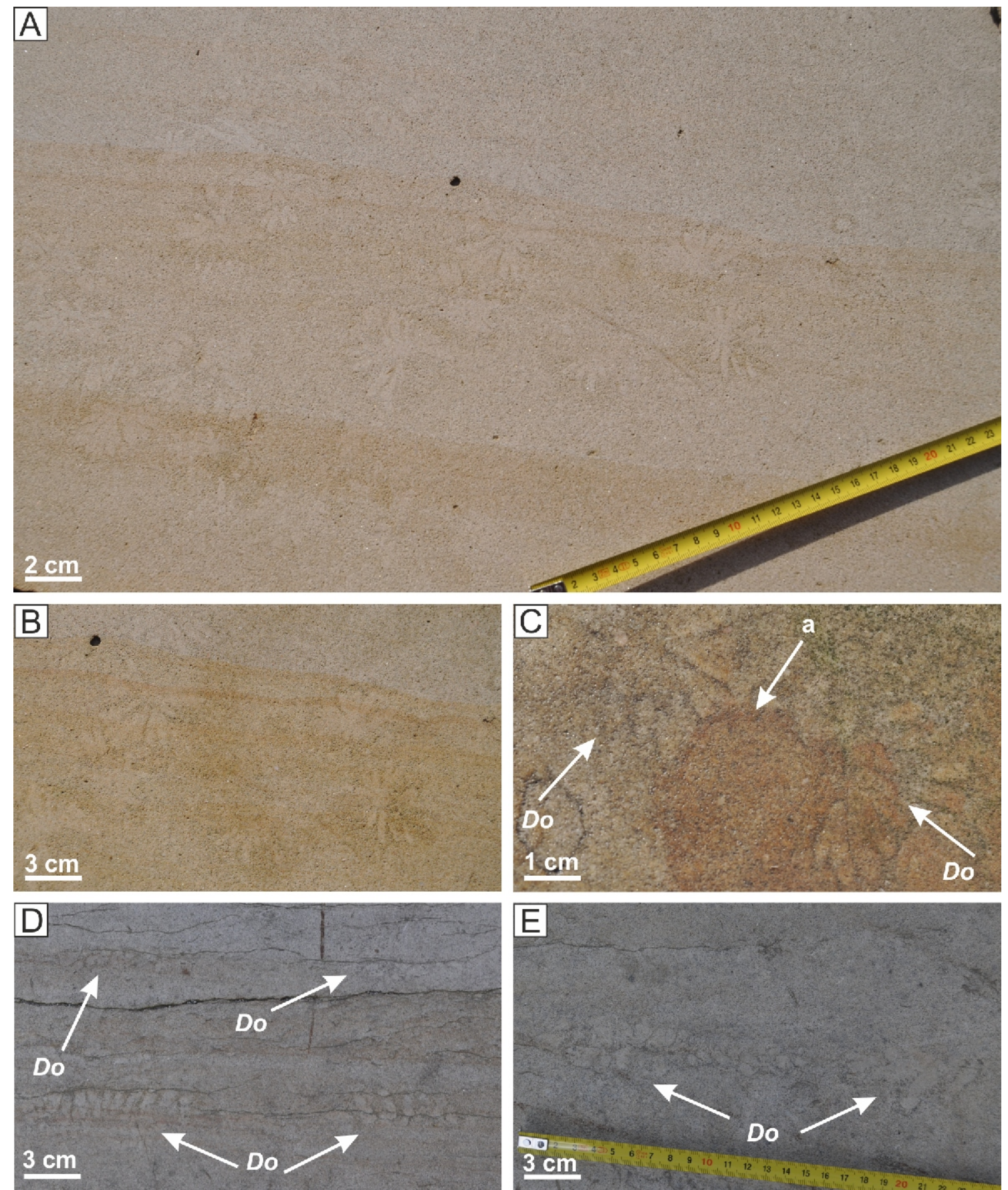

Fig. 7. Dactyloidites ottoi from the middle Turonian sandstones

A, B - Dactyloidites ottoi, Szklary (cut surfaces of loose sandstone blocks, parallel to bedding); C - Dactyloidites ottoi and questionable specimen in the form of a concave ring, loose sandstone block, Szklary; D, E - Dactyloidites ottoi in vertical section (loose blocks, Wojsławice); Do - Dactyloidites ottoi, a - questionable trace fossil

D e s c r i p t i o n. - Ophiomorpha nodosa appears mainly as single, tubular isolated, unbranched shafts with pelleted walls (horizontal, vertical or inclined) or create boxwork consisting of tubular tunnels. Pellets are ovoid or elongate, up to $1 \mathrm{~cm}$ in length. The visible length of the studied specimes varies from a few $\mathrm{cm}$ to several dozen $\mathrm{cm}(25-30 \mathrm{~cm})$, while width from 0.5 to $1.5 \mathrm{~cm}$. Elliptical to circular cross-sections are also common. In the studied deposits the swollen chambers (turn arounds) are abundant (Fig. 8B-D, F-K, M). They are usually from $2 \mathrm{~cm}$ up to $10 \mathrm{~cm}$ in length and $2 \mathrm{~cm}$ up to $6 \mathrm{~cm}$ in width. The wall of these swollen chambers is usullay composed of large pellets, up to $1 \mathrm{~cm}$ long. Some cross-sections with poorly preserved walls were determined as Ophiomorpha isp. (Fig. 8M) or ?Ophiomorpha isp. (Figs. 9D and 10F).

Remarks. - These specimens are assigned to Ophiomorpha nodosa due to the presence of a characteristic pelleted wall, diagnostic for this ichnogenus (Fig. 8B-D, F-K; Frey et al., 1978) and chambers typical of ophiomorphids (Uchman, 1995; Seilacher, 2007). Niebuhr and Wilmsen (2016) postulated replacement of Ophiomorpha nodosa Lundgren, 

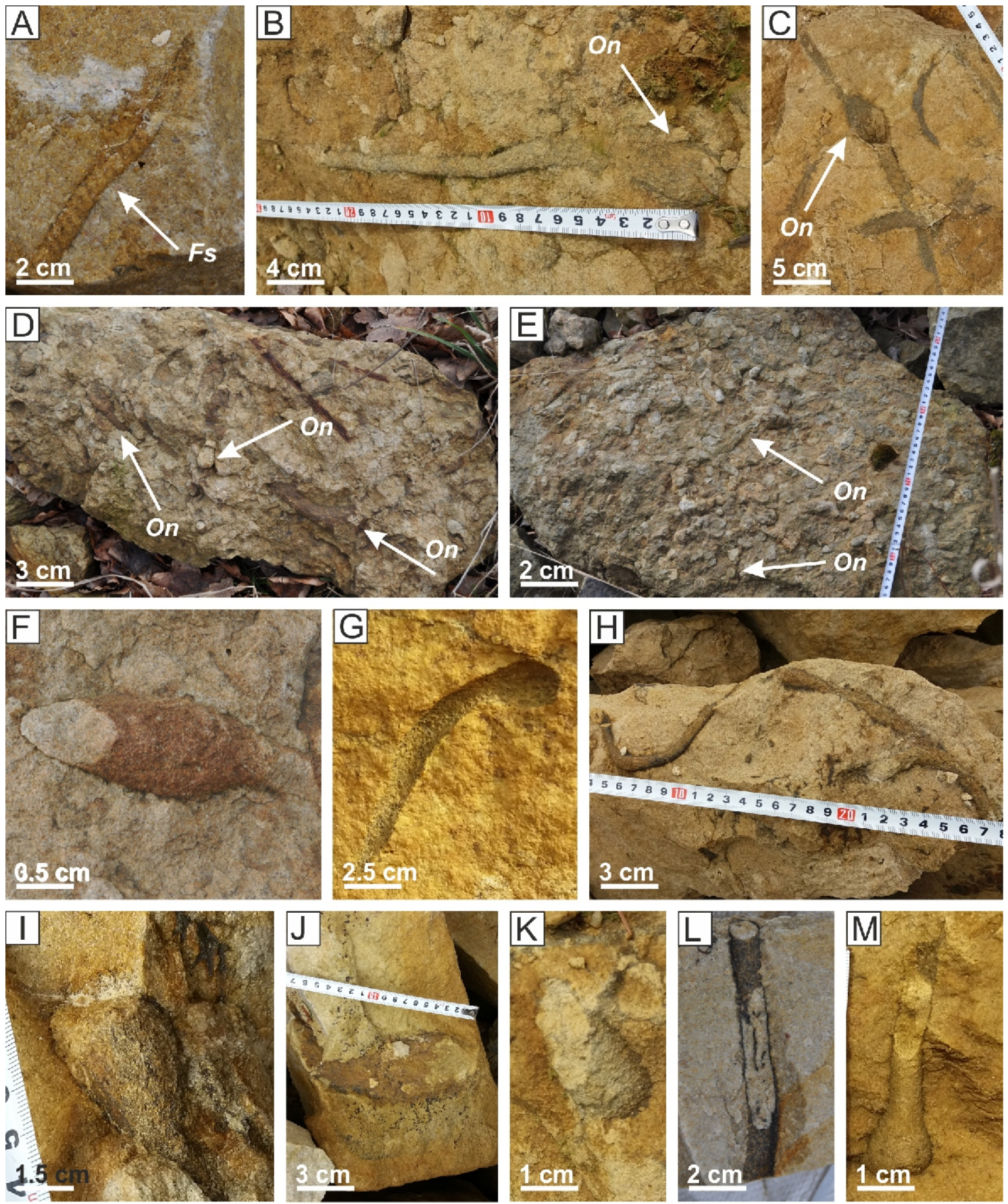

Fig. 8. Funalichnus strangulatus and Ophiomorpha nodosa from Długopole Górne Quarry

A - Funalichnus strangulatus, loose block; MGUWr-6757s; B, C - Ophiomorpha nodosa on the surfaces of loose sandstone blocks; D, E - Ophiomorpha nodosa on the upper surfaces of sandstone slabs; F-M - Ophiomorpha nodosa and its swollen chambers on the sandstone surfaces, G-M - rocks in situ, F, H-L - loose blocks; abbreviations: Fs Funalichnus strangulatus, On - Ophiomorpha nodosa

1891 by Ophiomorpha saxonica (Geinitz, 1842) on the basis of work by Geinitz (1842: Taf. XXIII, fig. 2), who defined Spongites saxonicus. They included into Ophiomorpha saxonica (Geinitz, 1842) some specimens described earlier by Chrząstek (2013a) as Ophiomorpha nodosa Lundgren, 1891. The taxonomy of trace fossils of the ophiomorid group is not simple (see papers by Fürsich, 1973; Frey et al., 1978; Schlirf, 2000, 2005; Rindsberg, 2018). It seems that some of the current specimens with very well preserved swollen chambers and large pellets (up to $1 \mathrm{~cm}$ ) might have been assigned to $O$. saxonica sensu
Niebuhr and Wilmsen (2016; Figs. 8C, D, F-K). However, some other specimens of Ophiomorpha with poorly preserved walls or walls built of smaller pellets, may be determined as $O$. nodosa (e.g., Fig. 8L, M).

Ophiomorpha ethologically is a domichnion or domichnion/fodnichnion (Frey et al., 1978; Uchman and Gaździcki, 2006). The potential trace makers are suspension- or deposit-feeders or farmers (Bromley, 1996). Ophiomorpha is produced by callianassid shrimps, decapods of the infraorders Gebiidea and Axiidea (Hyžný et al., 2015, 2018). This 

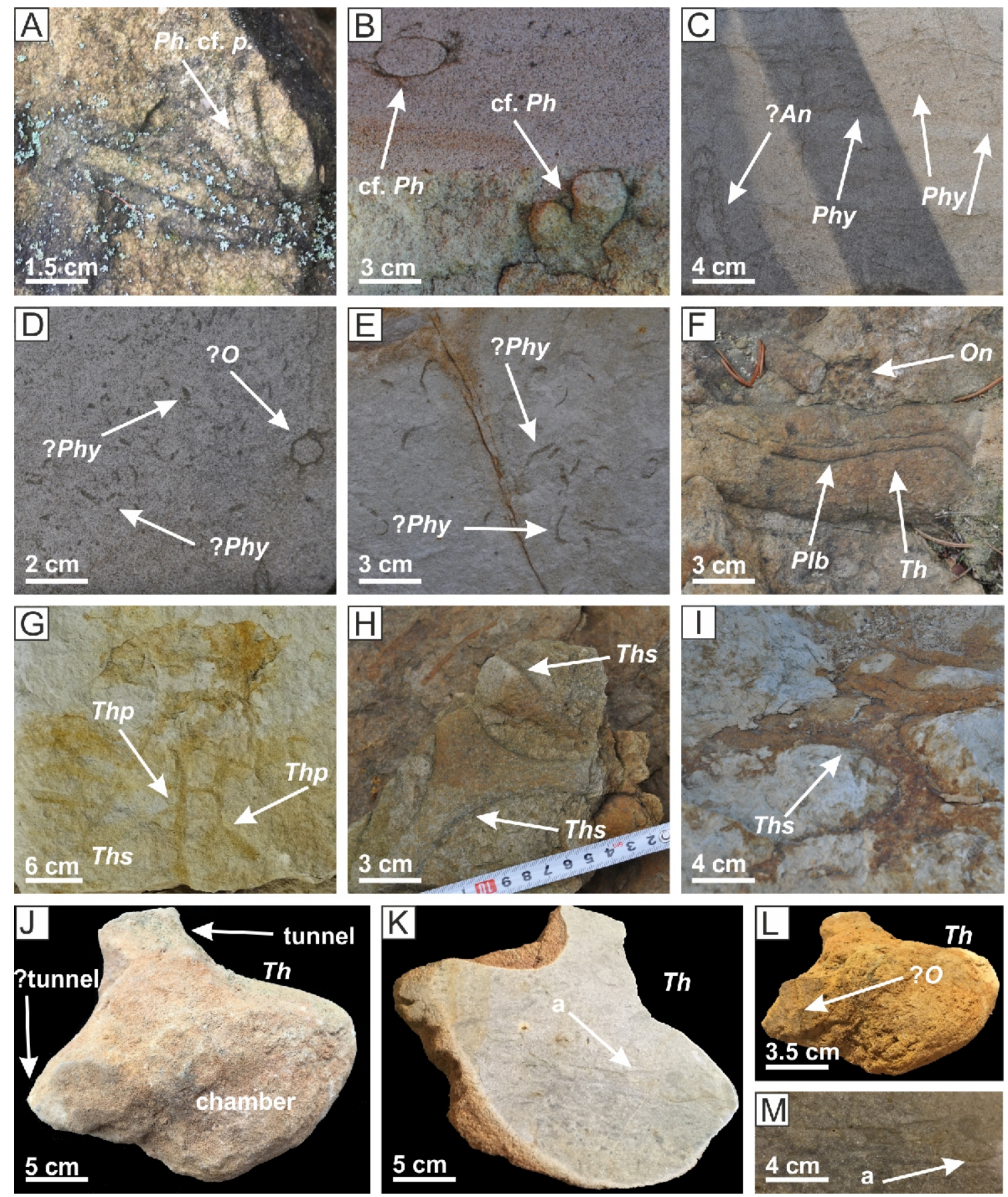

Fig. 9. Trace fossils from the middle Turonian sandstones

A - Phycodes cf. palmatus, Długopole Górne Quarry, loose block; B - cf. Phycodes isp., Wojsławice, loose block; C Phycosiphon incertum, ?Ancorichnus isp., Wojsławice (surface parallel to bedding); D, E - ?Phycosiphon isp. and ?Ophiomorpha isp., Wojsławice and Szklary, respectively (cut surfaces of sandstone); $\mathbf{F}$ - Planolites beverleyensis in Thalassinoides isp. filling, Ophiomorpha nodosa, Długopole Górne Quarry (rock fragment); G - Thalassinoides paradoxicus, Wojsławice (bedding plane, loose sandstone block); specimen found by R. Niedźwiedzki, photograph - R. Niedźwiedzki; H, I -Thalassinoides suevicus type A, Długopole Górne Quarry (upper surfaces of loose block); J - Thalassinoides chamber, Długopole Górne Quarry (extracted from rock in situ); K - vertical cross-section of a chamber, a - ?crustacean trace fossil; $\mathbf{L}-$ ?Ophiomorpha isp. on the outer surface of a Thalassinoides chamber; $\mathbf{M}$ - crustacean trace fossil (?) preserved inside Thalassinoides chamber (in cross-section); abbreviations: ?O - ?Ophiomorpha isp., Ph. cf. p. - Phycodes cf. palmatus, cf. Ph - cf. Phycodes isp., Plb - Planolites beverleyensis, Thp - Thalassinoides paradoxicus, Ths - Thalassinoides suevicus, Th - Thalassinoides isp.; other abbrevations as in Figures 5 and 6 

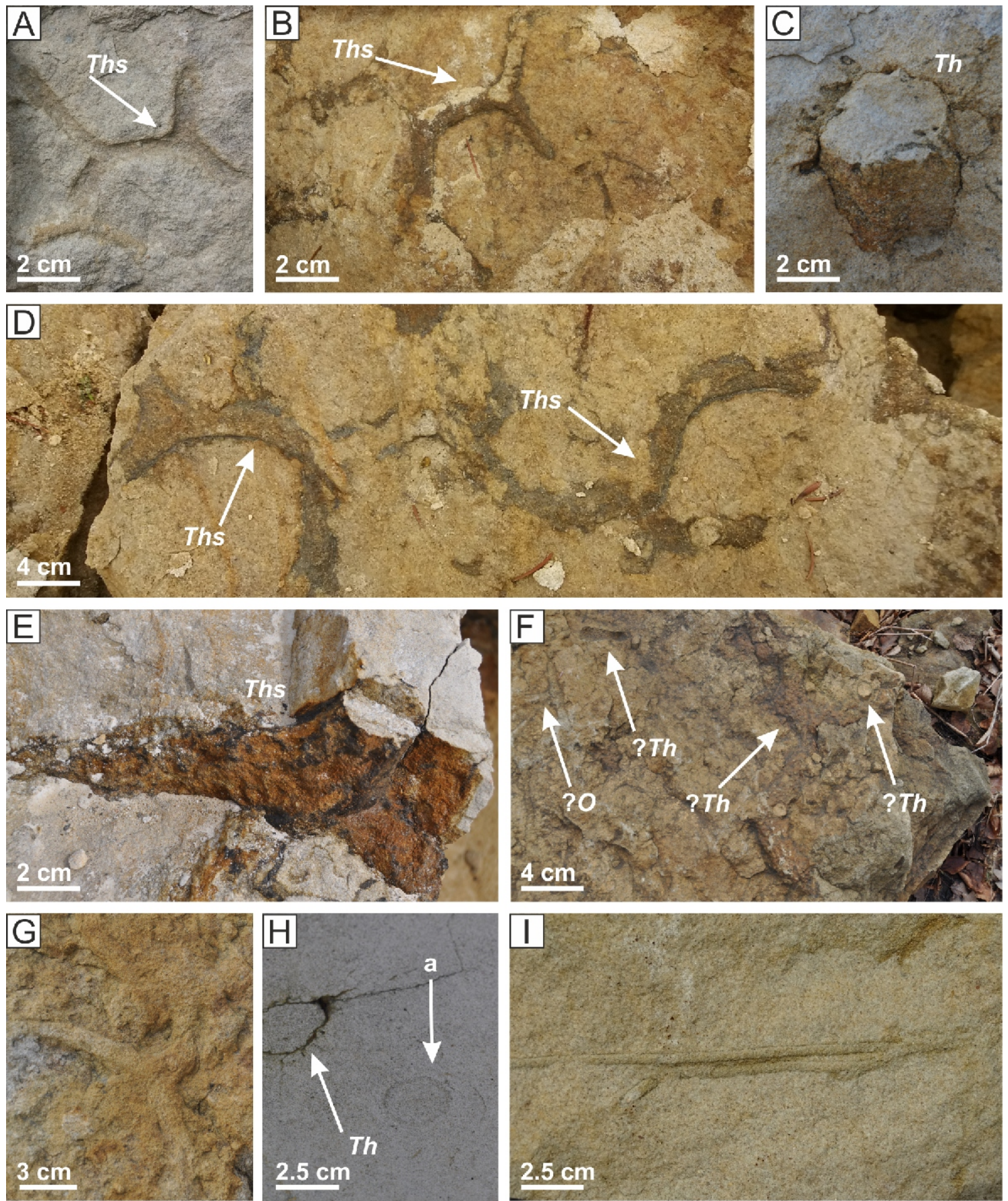

Fig. 10. Thalassinoides and questionable trace fossils from the middle Turonian sandstones

A, B - Thalassinoides suevicus type B, Długopole Górne Quarry (upper surfaces of loose sandstone blocks); C cross-section of Thalassinoides isp., Wojsławice (loose block); D, E - Thalassinoides suevicus type A, Długopole Górne Quarry (bedding planes, rock fragments); F - ? Thalassinoides isp. and ?Ophiomorpha isp., Długopole Górne Quarry (loose sandstone blocks); G - ?Thalassinoides isp., upper surface of loose block, Długopole Górne Quarry. H cross-section of Thalassinoides isp., a - questionable specimen similar to ? Schaubcylindrichnus, Szklary (surface parallel to bedding, loose sandstone slab); I - questionable trace fossil resembling Tisoa, Wojsławice (upper surface of sandstone block); specimen collected by R. Niedźwiedzki, photograph - R. Niedźwiedzki; ?Th - ?Thalassinoides isp., other abbreviations as in Figure 9 
ichnospecies characterizes the Skolithos and Cruziana ichnofacies (MacEachern et al., 2007, 2012). In shallow-marine siliciclastic deposits Ophiomorpha nodosa occurs from the foreshore to the upper offshore, being common in middle-upper shoreface settings (Curran, 1985; Pollard et al., 1993; Goldring and Pollard, 1995; Leaman et al., 2015). The stratigraphical range of Ophiomorpha is from Permian to Holocene (Frey et al., 1978) or from the Pennsylvanian (Anderson and Droser, 1998).

Phycodes Richter, 1850

Phycodes cf. palmatus (Hall, 1852)

(Fig. 9A, B)

M a t e r i a l. - Two specimens (epichnia) preserved in full relief on sandstone blocks and a few in cross-section from Długopole Górne Quarry and Wojsławice.

D e s c ription. - The specimens occur as horizontal, branched structures, which consist of a few (2-5) rounded, smooth, cylindrical tunnels. These tunnels seemingly originate from nearly the same point, maybe from a single stem, in a palmate-like structure (Fig. 9A). However, this part of the trace fossils is poorly developed. The cylindrical tunnels are oval in cross-section (Fig. 9B). The diameter of the cylindrical branches is $1.0-2.5 \mathrm{~cm}$, while the length of individual tunnels is up to $5.0 \mathrm{~cm}$

$\mathrm{R}$ e $\mathrm{m}$ a r k s. - These specimens show close similarity to those reported by Han and Pickerill (1994: fig. 5/12), Knaust (2004: fig. 7/3) and Singh et al. (2008: fig. 4b, c), described as Phycodes palmatus (Hall, 1852), which is a horizontal bundle burrow and consists of a few thick and rounded branches (tubes) that originate in a palmate structure. The occurrence of a branched structure, subdivided into $2-5$ cylindrical tunnels probably diverging from the same point, and oval cross-sections, might suggest similarity to Phycodes palmatus. However, the current specimens are fragmentarily preserved, e.g. the initial stem is not well visible, and so they were assigned to Phycodes cf. palmatus and cf. Phycodes isp., respectively (Fig. 9A, B).

Phycodes is regarded as a fodinichnion of deposit-feeders, probably annelids or sea-pens (Fillion and Pickerill, 1990; Han and Pickerill, 1994). It is typical of the Cruziana ichnofacies (MacEachern et al., 2012) and characterizes mainly shallow-marine settings (Singh et al., 2008). Phycodes is common in lower shoreface deposits (Buatois and Mángano, 2011; Pemberton et al., 2012), though can also appear in shallower and deeper settings. This ichnogenus is known from the lower Cambrian to the Pliocene (Han and Pickerill, 1994).

Phycosiphon Fischer-Ooster, 1858

Phycosiphon incertum Fischer-Ooster, 1858 (Figs. 5B and 9C)

Material. - Several specimens preserved as cross-sections in sandstone blocks, Wojsławice.

Description. - Phycosiphon occurs as a small spreite burrow consisting of repeated narrow, U-shaped lobes with dark fine-grained cores and a light coarse-grained mantle. The spreite, which extends between the arms of the lobes, is made of the same material as the mantle of the tube. The burrow system is parallel to bedding. The specimens occur also as several black circular dots, comma-shaped dots and fish-hook shapes. The diameter of the tubes is up to $1 \mathrm{~mm}$ and the lobes are up to $1 \mathrm{~cm}$ wide (Figs. 5B and 9C). A well preserved lobe, $5.0 \mathrm{~cm}$ in length, is observed. In some cases, the preserved fragments of individual lobes are up to $1 \mathrm{~cm}$ long (Figs. 5B and 9C). Spreiten between lobes are poorly and only fragmentarily preserved (Fig. 5B).

$\mathrm{R}$ e marks. - The well preserved recurving lobes or many characteristic black, comma-shaped dots and fish hook shapes (Figs. 5B and 9C) suggests the assignment to Phycosiphon incertum (cf. Wetzel and Bromley 1994: figs. 4-6; Bromley, 1996: fig. 8.4; Naruse and Nifuku, 2008; RodríguezTovar et al., 2014a).

Phycosiphon is considered to be a fodinichnion (Wetzel and Bromley, 1994) or a pascichnion/fodinichnion (RodríguezTovar et al., 2014a). It is typical of the Cruziana, Zoophycos and Nereites ichnofacies (Knaust, 2017). Phycosiphon trace makers may be small vermiform organisms, being selective deposit feeders (cf. Bednarz and Mcllroy, 2009). Phycosiphon is common in oxygen- and nutrient-rich fine-grained siliciclastic softground deposits (Rodríguez-Tovar et al., 2014a). This ichnospecies is characteristic of the proximal and distal lower shoreface to lower offshore and even deep-sea settings in calmer conditions (Dashtgard et al., 2012; Vakarelov et al. 2012; Wesolowski et al., 2018; MacEachern and Bann, 2020). It is known from the Cambrian to the Holocene (Naruse and Nifuku, 2008; Hammersburg et al., 2018).

\section{?Phycosiphon isp.} (Figs. 6H, J and 9D, E)

$\mathrm{M}$ a t e ri a I. - Some questionable specimens preserved as cross-sections, Szklary and Wojsławice.

D e s c r i p t i o n. - Abundant, horizontal cylindrical specimens preserved as cross-sections (Fig. 9D, E) are meandering, cylindrical and unbranched burrows. The specimens are mostly curved, rarely straight. The burrows are densely packed. The specimens are elliptical in cross-section. Their filling is darker than the host rock. Their length is from $1.0-3.0 \mathrm{~cm}$, while $0.2-0.4 \mathrm{~cm}$ wide. One specimen, which occurs as a U-shaped lobe, $2.0 \mathrm{~cm}$ long and $1.0 \mathrm{~cm}$ wide, is also present (Fig. $6 \mathrm{H}$ ).

$\mathrm{R}$ e $\mathrm{m}$ a $\mathrm{rk} \mathrm{s}$. - These questionable specimens show similarities to Phycosiphon in having a winding course, with thickness and darker fill typical of this ichnogenus. They also seem similar to Planolites, especially ?Planolites montanus Richter, 1937 (cf. Patel et al., 2008: fig. 3g, f; Chrząstek, 2013b: pl. 3/8; Stachacz, 2016: fig. 12D), in their winding course, which usually changes over short distances (cf. Rodríguez-Tovar et al., 2014b: fig. 7G; Feng et al., 2017: figs. 8H, 9E). However, these burrows are moderately to highly curved as for Planolites. The state of preservation is not good, thus these specimens were assigned as ?Phycosiphon isp. The specimens also show some resemblances to Macaronichnus segregatis degiberti Rodríguez-Tovar and Aguirre, 2014 due to their winding course (see also Nara and Seike, 2019; Olivero and López Cabrera, 2020: fig. 5). The main difference is the lack of a mineralogical segregation within a tube, typical of this ichnogenus (Clifton and Thompson, 1978; Bromley et al., 2009).

Planolites Nicholson, 1873

Planolites beverleyensis (Billings, 1862) (Fig. 9F) 
Material. - One specimen preserved in a Thalassinoides isp. infill, co-occurring with Ophiomorpha nodosa; Długopole Górne Quarry.

D e s c r i p t i o n. - The specimen appears as a straight to winding, unbranched cylindrical horizontal tunnel, without wall, elliptical in cross-section. The fill of a burrow may be slightly different to the surrounding rock (Thalassinoides filling). The outer surface of the burrow is moderately smooth. The length is $8 \mathrm{~cm}$, width $0.5 \mathrm{~cm}$.

$\mathrm{R}$ e $\mathrm{m}$ arks. - The specimen shows similarities to the ichnogenus Planolites Nicholson, 1873 in having a slightly undulating, flattened, unbranched, cylindrical tunnel, without wall (Fig. 9F). It is especially similar to Planolites beverleyensis (Billings, 1862) described by Chrząstek (2013b: pl. 3/8), Stachacz (2016: fig. 12C) and Feng et al. (2017: figs. 5C, D, 10D, E), which usually has a straight to slightly winding course and flattened tunnel. It differs from Palaeophycus Hall, 1847 in the lack of wall and constant width of the cylindrical tunnel (cf Chrząstek, 2013b: pl. 2/2; Stachacz, 2016: fig. 12F). The specimen (Fig. 9F) occurs in a Thalassinoides infill. Probably, for some producers of trace fossils, other burrows could be additional food resources (cf. Izumi, 2015; Knaust, 2020b).

Planolites is regarded as a pascichnion or fodinichnion produced by deposit-feeders or predators, mainly polychaetes (Alpert, 1975; Pemberton and Frey, 1982; Keighley and Pickerill, 1995; Bromley, 1996; Schlirf, 2003) or molluscs (Knaust, 2007). This ichnogenus is common in the Skolithos and Cruziana ichnofacies (Frey and Seilacher, 1980). This eurybathic and facies-crossing ichnogenus is abundant in shallow-marine settings (lower shoreface-lower offshore; Pemberton et al., 2001, 2012; Buatois and Mángano, 2011; MacEachern and Bann, 2020). It is known from the Ediacaran to the present (Häntzschel, 1975; Uchman, 1998; Mángano and Buatois, 2016).

Thalassinoides Ehrenberg, 1944

Thalassinoides paradoxicus Kennedy, 1967 (Fig. 9G)

$\mathrm{M}$ a t e r i a l. - One specimen preserved on a sandstone slab, Wojsławice. Two specimens preserved on sandstone blocks were reported by Chrząstek (2013a: fig. 10A, B).

De s c ription. - Cylindrical, unlined, irregularly branched specimen, which forms a burrow network. Vertical, horizontal and inclined shafts also appear. T-shaped branching pattern predominant relative to Y-shaped branches. Some swellings are present. The specimen diameter ranges from $0.7-1.5 \mathrm{~cm}$. The visible length is up to $35 \mathrm{~cm}$.

R e marks. - The occurrence of irregular pattern of branching, in which T-shaped branches of variable diameter predominate, suggests assignment to Thalassinoides paradoxicus (cf. Howard and Frey, 1984). It does not differ from the specimens described by and Knaust (2017: fig. 5.159b; 2020a: fig. 1c, d) and Chrząstek et al. (2018: fig. 8A). The specimen differs from $T$. suevicus in the presence of predominantly vertical components and in having more irregularly arranged ramifications (cf. Carmona et al., 2008).

It is regarded as a domichnion, fodinichnion or agrichnion (Myrow, 1995; Bromley, 1996; Ekdale and Bromley, 2003). The possible trace makers are crustaceans (thalassinidean shrimps, crabs, lobsters, crayfish) or cerianthid sea anemones, fish, enteropneusts (Frey et al., 1984a; Myrow, 1995 Dworschak and Rodrigues, 1997; Ekdale and Bromley, 2003;
Neto de Carvalho et al., 2007). Thalassinoides is typical of the Cruziana and Glossifungites ichnofacies (MacEachern et al., 2007, 2012), but can appear also in the Psilonichnus, Teredolites, Zoophycos and Nereites ichnofacies. Thalassinoides paradoxicus characterizes soft- and firmgrounds (cf. Knaust 2020a: fig. 2). Thalassinoides can appear in deposits ranging from marginal marine to deep sea, but in siliciclastic deposits is especially abundant in well-oxygenated shallow marine settings (Archer and Maples, 1984), in the distal lower shoreface (Pemberton et al., 2001, 2012; Uchman and Krenmayr, 2004; Buatois and Mángano, 2011). It ranges from the Cambrian (Mikuláš, 2000) to the Holocene (Mángano and Buatois, 2016), being common from the Ordovician (Jin et al., 2012; Chrząstek and Pluta, 2017).

\section{Thalassinoides suevicus (Rieth, 1932)}

(Figs. 9F, $\mathrm{H}-\mathrm{M}$ and $10 \mathrm{~A}-\mathrm{E}$ )

M a t e ri a I. - Several specimens preserved on upper sandstone surfaces (quarry walls, sandstone blocks) and as cross-sections, Długopole Górne Quarry, Szklary, Wojsławice (MGUWr-6759s). This ichnogenus was described by Chrząstek (2013a: fig. 9C-F) from the current site. One probable turning chamber of Thalassinoides was also recognized (Fig. 9J-M).

Description: The specimens appear as horizontal, cylindrical, unlined burrows with a Y-shaped branching pattern, which commonly forms a boxwork on the sandstone surface (Figs. 9l and $10 A, B, D)$. Two different categories of burrows were distinguished: Thalassinoides suevicus type A $(3.0-5.5 \mathrm{~cm}$, up to $7 \mathrm{~cm}$ in diameter; Figs. 9F, H, I and 10C-E) and T. suevicus type $\mathrm{B}(1.5-2.0 \mathrm{~cm}$ in diameter; Fig. 10A, B). The visible length is up to $80 \mathrm{~cm}$ (Fig. 10D). The Thalassinoides filling differs from the surrounding rocks in colour, being darker, rusty or brownish. Some cross-sections, described as Thalassinoides isp. also appear (Fig. 10C, H). The other specimen occurs as a structure, $30 \mathrm{~cm}$ in length, up to $16 \mathrm{~cm}$ high and $11 \mathrm{~cm}$ wide, which consists of a vertical to oblique cylindrical shaft, $7 \mathrm{~cm}$ in diameter, terminating in an oval chamber, elliptical in shape (Fig. 9J-M). At the left end of the chamber there may be a second tunnel, $8.5 \mathrm{~cm}$ in length and $7 \mathrm{~cm}$ in width (Fig. 9J). The angle between the two horizontal tunnels is 120 degrees. On the outer surface and in the cross-section of the chamber $(21 \mathrm{~cm}$ long), some other trace fossils appear, e.g., Ophiomorpha (Fig. 9K-M).

$\mathrm{R}$ e $\mathrm{m}$ a r k s. - The study specimens show strong affinities to Thalassinoides suevicus in having a predominantly Y-shaped branching pattern and boxwork (Figs. 9H, I and 10A, B, D). The burrows of Thalassinoides are clearly visible on the sandstone surfaces due to the contrasting brownish infill, especially when they form a branching network (Figs. 9H, I and 10B, D). Some Thalassinoides openings (Figs. 9J and 10C, H) seem to be slightly resemble Ophiomorpha irregulaire Frey, Howard, Pryor, 1978 (Frey et al. 1978; López Cabrera and Olivero, 2014) in having "flame-like structures" (Fig. 10C; cf. Boyd et al., 2012), though these structures might be caused by compaction. The specimen shown in Figure $9 \mathrm{~J}-\mathrm{L}$, due to the presence of a slightly flattened chamber and two canals, suggests assignment to Thalassinoides, most probably to $T$. suevicus. The chamber seems to be swollen (turn around) at the diverging point of the ophiomorid burrow, perhaps used by the trace makers for changing the direction of locomotion or for feeding, e.g., for storage of detritus for later consumption (see discussion in Chrząstek et al., 2018 and references therein). The specimen shows also some 
affinities in shape to Macanopsis plataniformis Muñiz and Mayoral, 2001 and M. astreptum Bown and Krauss, 1983 in having a cylindrical subvertical tunnel and basal chamber. The main difference is the presence of two cylindrical tunnels in the study specimen instead one.

\section{?Thalassinoides isp.} (Figs. 10F, G)

M a te ri al. - Two epichnial specimens preserved on sandstone blocks (Długopole Górne Quarry).

D e s c riptio n. - The study specimens are preserved as horizontal, branched burrows with scratch marks, resembling longitudinal ridges, on their surfaces (Fig. 10G). Some circular, ?sandy cores (cross-sections) with paler filling are observed (Fig. 10F). The tunnels are $4 \mathrm{~cm}$ wide and up to $40 \mathrm{~cm}$ long. The cross-sections of these specimens are smaller in diameter than the those of the cylindrical tunnels. They are $1.0-1.5 \mathrm{~cm}$ in width (Fig. 10F).

$\mathrm{R}$ e $\mathrm{m}$ a r k s. - These specimens show some affinities to two ichnogenera, Thalassinoides paradoxicus Kennedy, 1967 and Lamellaecylindrica paradoxica (Woodward, 1830; cf. Knaust 2020a: fig. 1a, c, d respectively) in creating horizontal burrows, consisting of ramified cylindrical tunnels with scratches and openings resembling sandy cores (Fig. 10F, G). They seem most similar to $T$. paradoxicus in having a variable diameter and probably vertical shafts, which have been seen in cross-section (see Fig. 10F). One probably blind tunnel was also observed (Fig. 10G). However, they differ from $L$. paradoxica in the lack of a thick, concentrically laminated muddy wall, observed in cores (Fig. 10F). The specimens also resemble Spongeliomorpha Saporta, 1887 (Fig. 10G, see Gibert and Ekdale, 2010: figs. 3, 4), in having a similar burrow morphology (e.g., branching pattern, blind tunnel), but differ in lacking the distinctly marked characteristic scratches typical of this ichnogenus.

Unidentified burrows (in open nomenclature) (Figs. $7 \mathrm{C}$ and $10 \mathrm{H}, \mathrm{I}$ )

M a t e r i a I. - Some poorly preserved, uncertain burrows, recorded as cross-sections (Figs. $7 \mathrm{C}$ and $10 \mathrm{H}$, Szklary). Another questionable specimen is preserved in full relief on a sandstone slab (Fig. 10I, Wojsławice).

D e s c ription. - The questionable specimens appear as concave rings (mounds with a central depression), of diameter up to $4 \mathrm{~cm}$ (Figs. $7 \mathrm{C}$ and $10 \mathrm{H}$ ). The second specimen appears as two parallel cylindrical tubes, which seem to be connected in the distal part (Fig. 10I). The surface of the burrow is smooth. The length is $12 \mathrm{~cm}$, and the width of the entire structure is $0.8 \mathrm{~cm}$. Each tube is $0.3 \mathrm{~cm}$ wide.

$\mathrm{R}$ e $\mathrm{m}$ a r k s. - Due to poor preservation the assignment of these specimens is uncertain, and so they are left in open nomenclature. The closest similarities are to ?Schaubcylindrichnus Frey and Howard, 1981 (Fig. 7C; Löwermark and Hong, 2006: figs. 4b, 5b) in having a circular ring with a central depression. On the other hand, similar structures have been suggested as ?jellyfish impressions (cf. Hammersburg et al., 2018: fig. 22/4-5; see discussion in Chrzastek, 2020). The study specimens also show affinities to trace fossils from the newly erected ichnofamily Siphonichnidae (Knaust, 2015: figs.
1, 2, 4E), which comprises burrows consisting of vertical tubes with core and mantle or lining (e.g., Siphonichnus Stanistreet, le Blanc Smith and Cadle, 1980 or Laevicyclus Quenstedt, 1879, see discussion in Chrząstek, 2020).

The other questionable specimen (Fig. 10I) shows some similarities to Tisoa de Serres, 1840, especially Tisoa habichi Lissón, 1904 (previously Diplocraterion habichi) or Paratisoa (cf. Knaust, 2019: figs. 1, 2), in having two cylindrical horizontal closely spaced tubes (cf. Knaust, 2019: figs. 8H, 10E, F). However, this doubtful structure might also represent Ophiomorpha.

BORINGS

\section{Entobia Bronn 1837}

Entobia isp.

(Fig. 11A, B)

M a t e ri a I. - Borings preserved in two bivalve moulds, Długopole Górne Quarry (MGUWr-6760s).

$\mathrm{D}$ e s c ription. - The specimens appear as circular to subcircular apertures of boxwork chambers interconnected by canals on the original shell surface. Aperture diameters range up to $0.5 \mathrm{~cm}$.

$\mathrm{R}$ e $\mathrm{m}$ a r k s. - The morphology indicates assignment to Entobia (cf. Bromley and D'Alessandro, 1984). The trace makers are sponges of the family Clionaidae (Bromley and D'Alessandro, 1984). The specimens belong to the Entobia or Gnathichnus ichnofacies and to the newly erected family Entobiaidae (cf. Wisshak et al., 2019). Frey and Seilacher (1980) erected the Trypanites ichnofacies, and Bromley and Asgaard (1993) the Entobia ichnofacies. Recently, the Entobia ichnofacies was suggested to comprise Mesozoic and Cenozoic records (since the Jurassic; see Gibert et al., 1998, 2007), with the Trypanites ichnofacies for Paleozoic records (El-Hedeny and El-Sabbagh, 2018). The Entobia ichnofacies, similarly to the Trypanites ichnofacies, corresponds to long-term bioerosion (deep-tier), while the Gnathichnus ichnofacies is associated with surficial bioerosion structures (shallow-tier). Earlier, MacEachern et al. (2007) regarded Entobia and Gnathichnus as ichnocoenoses in the Trypanites ichnofacies. Due to the shallow-tier occurrence in bivalve shells the current specimens might represent the Gnathichnus ichnofacies. Entobia may occur in a relatively wide spectrum of depositional settings, ranging from marginal-marine to offshore (after Buatois and Mángano, 2011; Demircan, 2012; El-Hedeny and El-Sabbagh, 2018). However, clionaid sponges, the possibly producers of Entobia, prefer low energy nearshore, shallow-marine environments (Schmidt-Neto et al., 2018). They range from Jurassic to present (Pineda Salgado et al., 2015) or from Devonian to Recent (Wilson, 2007).

\section{ASSOCIATED BODY FOSSILS}

In the middle Turonian deposits studied, body fossils, the bivalves ?Brachidontes sp. (Fig. 11C), Lima canalifera Goldfuss, 1836 (Fig. 11D-F; MGUWr-6761s), Pinna (Pinna) cretacea (Schlotheim, 1813) (Fig. 11G; MGUWr-6762s) and Rhynchostreon suborbiculatum (Lamarck, 1801) (Fig. 11C, H-J), were also collected.

?Brachidontes Swainson, 1840 (suspension-feeder bivalve) is regarded as an important palaeoecological indicator, common in the shallow littoral zone (Aguirre et al., 2006; Morton et al., 2020). This genus is typical of turbulent, moderate to high 

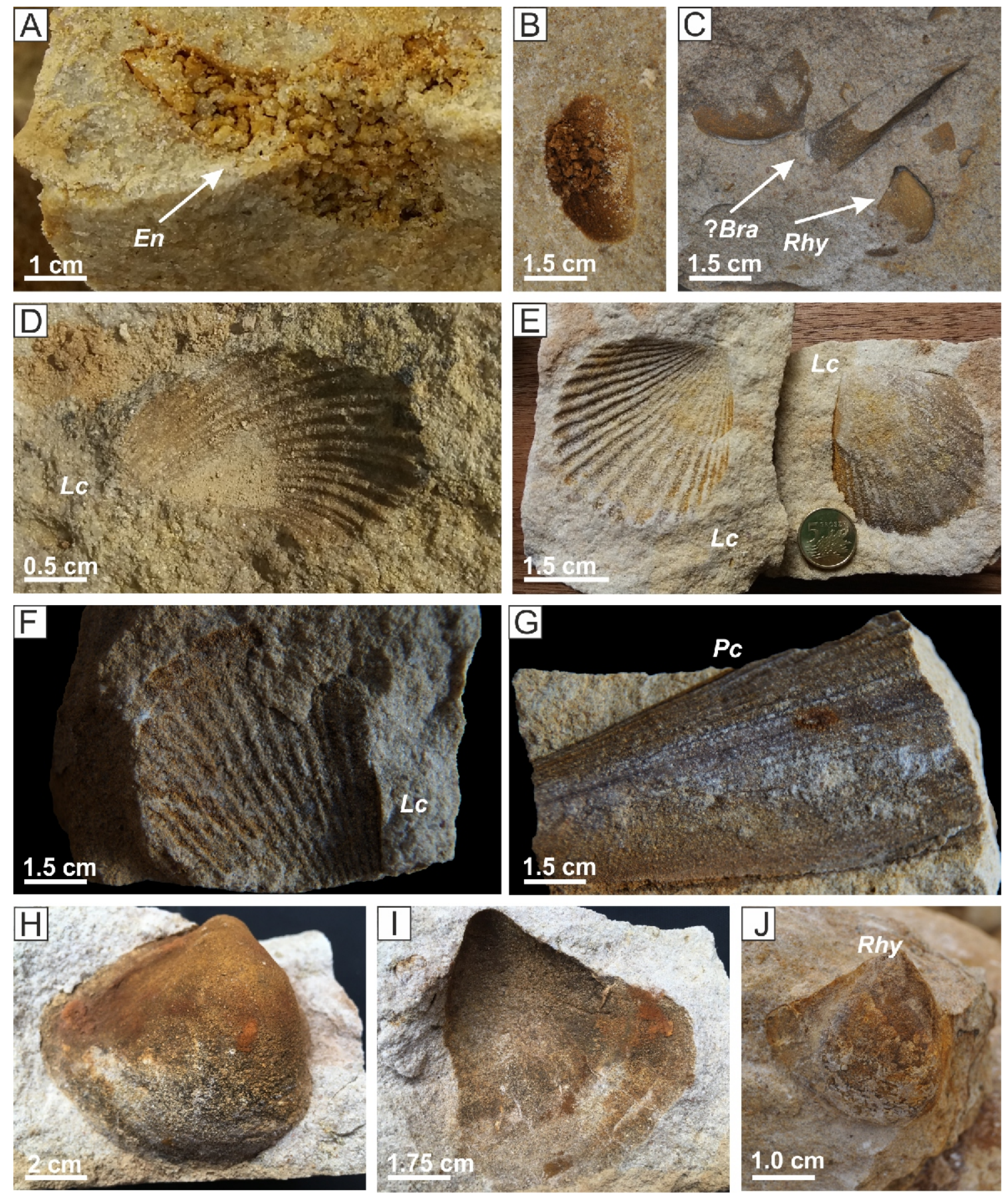

Fig. 11. The boring Entobia and body fossils from Długopole Górne Quarry

A, B - Entobia isp.; MGUWr-6760s; C - ?Brachidontes sp., Rhynchostreon suborbiculatum (rock in situ, wall of the quarry); D-F - Lima canalifera; MGUWr-6761s (loose blocks); G - Pinna (Pinna) cretacea; MGUWr-6762s (rock fragment); H - Rhynchostreon suborbiculatum (loose block, positive specimen); I - Rhynchostreon suborbiculatum, the same specimen as in $\mathrm{H}$, preserved as negative; $\mathbf{J}$ - Rhynchostreon suborbiculatum (loose block); abbreviations: En Entobia isp., ?Bra - ?Brachidontes sp., Lc - Lima canalifera, Pc - Pinna (Pinna) cretacea, Rhy - Rhynchostreon suborbiculatum

energy, normal salinity waters, or in some cases brackish waters (polyhaline-euryhaline, see Scott, 1970; Sara and Pirro, 2011). Other authors (Scott, 1970; Ekdale and Ekdale, 2018) also reported this genus from shallow, nearshore marine settings.

The bivalve Lima canalifera Goldfuss, 1836 is common in well-oxygenated environments, usually up to $40 \mathrm{~m}$ deep (Wilmsen et al., 2007; Schneider et al., 2011). According to the cited authors, this taxon is known from the Cenomanian to Campanian in Germany. Lima canalifera was previously reported by Chrząstek (2013a) from the current site. The study specimens show similarities to $L$. canalifera in having up to 20 radial costae, instead of 30 ribs as possesses $L$. multicostata Geinitz, 1839 (cf. Schneider et al., 2011 and references therein). 
Pinna (Pinna) cretacea is a suspension-feeder, that inhales waters at the posterior end of the shell, which is usually elevated above the sea floor (cf. Seeling and Bengtson, 2003: fig. 4A-C; Bengtson et al., 2014: fig. 2). The study specimen might represent Pinna (Pinna) cretacea cretacea, a new subspecies adopted recently by Bengtson et al. (2014), in having several ribs (up to 18) and nearly straight dorsal and ventral margins. This subspecies, according to the cited authors, is typical of the Turonian, while the other subspecies Pinna (Pinna) cretacea brevis usually appears from the late Turonian to the Coniacian. Recent Pinnidae occur mainly in shallow waters, under low energy conditions, from a few metres to $50 \mathrm{~m}$ down, commonly on the lower shoreface (Bengtson et al., 2014; Carmona et al., 2020). Pinna (Pinna) cretacea is a stratigraphically (Albian-Maastrichtian) and geographically widely distributed species (Seeling and Bengtson, 2003). This taxon was described from the middle Turonian of Saxony, Germany by Wilmsen and Niebuhr (2014b).

Rhynchostreon suborbiculatum is a nearshore oyster, which is characteristic of shallow-marine, moderate to high energy, well-oxygenated and nutrient-rich settings (see Seeling and Bengtson, 1999; Moussavou, 2017; Tröger 2017). Abdelhady (2009) reported this species from normal salinity environments. Dhondt et al. (1999) and Ayoub-Hannaa and Fürsich (2011) described it from mid-shelf environments (25-30 m deep), and Herkat (2007) and Richardt et al. (2013) from settings up to $50 \mathrm{~m}$ deep. According to Seeling and Bengtson (1999) and Nagm and Boualem (2019), Rhynchostreon (earlier Exogyra columba; cf. Tröger, 2003), a cosmopolitan species, is widely distributed in the Cenomanian-lower Turonian of the Tethys Ocean (Tröger, 2003; Ayoub-Hannaa et al., 2014). According to these authors, its appearance in the Upper Cretaceous of Europe (North Temperate Realm), indicates a northward faunal migration (a strong southern influence). Thus, exogyrine oysters are a very useful tool for palaeobiogeographic reconstructions (Ayoub-Hannaa et al., 2014). The oyster Rhynchostreon is abundant in the Upper Cretaceous of Germany (Saxony, Bavaria) and is also widespread in the Bohemian Cretaceous Basin (Tröger, 2003, 2017; Schneider et al., 2013; Janetschke and Wilmsen, 2014).

\section{PALAEOENVIRONMENTAL RECONSTRUCTION BASED} ON TRACE AND BODY FOSSILS

CHARACTERISTIC OF TRACE FOSSIL ASSEMBLAGE

In the middle Turonian sandstones of Długopole Górne Quarry an ichnoassemblage comprising burrows and borings was found, representing several ethological categories: domichnia or domichnia/fodinichnia (Ophiomorpha, Funalichnus), fodinichnia (Dactyloidites, Asterosoma, Thalassinoides, Phycodes, Phycosiphon), repichnia (Curvolithus) repichnia/ pascichnia (?Ancorichnus) and pascichnia (Planolites). Borings Entobia (domichnia) were also recorded. In the assemblage studied fodinichnia prevail, while domichnia or domichnia/ fodinichnia are common and repichnia/pascichnia rare. Trace makers are suspension- and deposit-feeders or carnivores. The trace fossils studied characterize the Skolithos and Cruziana ichnofacies. Ichnological analysis shows the presence of a moderately diverse trace fossil assemblage (13 ichnogenera, 23 ichnospecies; Table 1). Of these, Palaeophycus, ?Macaronichnus, Curvolithus, Ophiomorpha and Thalassinoides were previously reported by Chrząstek (2013a). Ophiomorpha is most abundant in the Długopole Górne Quarry section, while Thalassinoides, Dactyloidites and Phycosiphon are common (Table 1). Other trace fossils are rare or very rare. Ichnodisparity is also moderate, with 11 architectural designs (two categories dominate, cf. Buatois et al., 2017). In these middle Turonian sandstones maze and boxwork burrows prevail (Ophiomorpha, Thalassinoides), while radial to rosetted burrows (Dactyloidites) are common. The collected trace fossils represent mainly shallow-tier (up to $15 \mathrm{~cm}$ deep, Ancorichnus, Curvolithus, Phycodes) and mid-tier (15-50 cm deep) assemblages, e.g., Asterosoma, Dactyloidites, Phycosiphon, Thalassinoides (cf. Rodríguez-Tovar et al., 2017). The Długopole Górne Quarry deposits are unbioturbated to commonly bioturbated (bioturbation index, $\mathrm{BI}=0-4)$. The highest values of bioturbation index $(\mathrm{BI}=4 ; 60-90 \%)$ are in the sandstone beds bioturbated by Dactyloidites and Ophiomorpha. Moderate bioturbation $(\mathrm{BI}=3 ; 30-60 \%)$ was recorded in beds bioturbated mainly by Thalassinoides and Phycosiphon.

ICHNOLOGICAL IMPLICATIONS ON DEPOSITIONAL ENVIRONMENT

The moderately diverse assemblage studied represents a wide spectrum of different ethologies and is characteristic of both the Skolithos and Cruziana ichnofacies (Pemberton et al., 2001; Pervesler and Uchman, 2004). Due to the presence of traces which represent different ethological categories, nutrients were available both in suspension and deposit (see Baucon and Neto de Carvalho, 2008).

Thalassinoides and Ophiomorpha, the most common ichnogenera in the Długopole Górne Quarry section, are abundant in lower shoreface settings (Pemberton et al., 2001, 2012; Uchman and Krenmayr, 2004; Pervesler et al., 2011; Bayet-Goll et al., 2015). In the uppermost part of the Długopole Górne section a large Thalassinoides chamber - turn around (21 cm in length), was found. Simlar enlarged chambers at diverging points of ophiomorids (Thalassinoides) were reported by Giannetti et al. (2007, up to $22 \mathrm{~cm}$ long) and El-Sabbagh et al. (2017, up to $18 \mathrm{~cm}$ long, see fig. 3) from shallow-marine settings. Chrząstek et al. (2018) reported crustacean burrows of similar size (Rosarichnoides sudeticus), consisting of eight swollen chambers (up to $10 \mathrm{~cm}$ long each), from an upper shoreface setting (Coniacian sandstones, North Sudetic Synclinorium). Dactyloidites, which is also common in the middle Turonian sandstones of Długopole Górne Quarry, is regarded as a good palaeonvironmental indicator, due to its occurrence under specific conditions (bathymetry, salinity, availability of nutrients) in a restricted environment, beneath the fair-weather wave base (cf. Uchman and Pervesler, 2007; Wilmsen and Niebuhr, 2014a and references therein). Moreover, the presence of rare, newly recognized trace fossils, such as ?Ancorichnus, Asterosoma, Dactyloidites, Funalichnus, Phycodes, Phycosiphon, Planolites indicate sedimentation of the deposits studied below the fair-weather wave base, in a lower shoreface setting (see Pemberton et al., 2001, 2012; Pokorný, 2008; Buatois and Mángano, 2011; Wilmsen and Niebuhr, 2014a). Planolites and Curvolitus are also described mainly from shoreface-upper offshore environments (Buatois et al., 1998; Pemberton et al., 2012). In the Długopole Górne section Phycosiphon commonly co-occurs with Dactyloidites (Fig. 6H, J) or with ?Ancorichnus isp. (Figs. 5B and 9C). These ichnotaxa have usually been reported from environments ranging from the lower shoreface to offshore (Desai and Saklani, 2014; Wilmsen and Niebuhr, 2014a; MacEachern and Bann, 2020). Moreover, Planolites beverleyensis appears also in a Thalassinoides infill (Fig. 10F). Earlier, Chrząstek (2013a), described ?Macaronichnus within a Thalassinoides infill from these deposits. Macaronichnus has usually been reported from foreshore-upper shoreface settings, but in storm-origin deposits can occur up to a lower shoreface setting (Pemberton et al., 
2001; Uchman and Krenmayr, 2004; Olivero and López Cabrera, 2020). The newly found borings Entobia are known from the marginal-marine to offshore settings (Wilson, 2007; El-Hedeny and El-Sabbagh, 2018), but with increasing water depths they become less common (Bromley and Asgaaard, 1993; El-Sabbagh, 2008). Schmidt-Neto et al. (2018) reported that in Mesozoic and Cenozoic deposits, Entobia occurs usually in settings below the fair-weather wave base.

In the ichnoassemblage studied, horizontal traces prevail, but vertical burrows also appear. Horizontal and radial burrows, attributable to deposit- or detritus-feeders (?Ancorichnus, Curvolithus, Asterosoma, Planolites, Dactyloidites, Phycosiphon, Phycodes, Thalassinoides), characterize low energy conditions typical of the proximal Cruziana ichnofacies (beneath the fair-weather wave base), while vertical ones, typical of suspension-feeders (Ophiomorpha, Funalichnus), point to more energetic conditions, characteristic of the distal Skolithos ichnofacies (slightly above the fair-weather wave base). Additionally, the boring Entobia, which characterizes the Gnathichnus ichnofacies, is also associated with low energy conditions, when the bivalve moulds were bioeroded (Belaústegui et al., 2015; Schmidt-Neto et al., 2018 and references therein). The moderate ichnodisparity of the assemblage, and the presence of burrows with horizontal spreiten, radial to rosetted structures or maze and boxwork burrows (cf. Buatois et al., 2017), also suggests the predominance of generally lower energy conditions during deposition of these sandstones. The proximal Cruziana ichnofacies suggests quiet sedimentation, under low energy hydrodynamic conditions on a distal lower shoreface, while the distal Skolithos ichnofacies is typical of more energetic conditions, probably connected with more common and abundant sand supplies, on a proximal lower shoreface. Dactyloidites, Phycosiphon, ?Ancorichnus, Phycodes and horizontal burrows of Ophiomorpha are commonly associated with fine- and medium-grained sandstones, and Asterosoma, Curvolithus, Thalassinoides and Ophiomorpha (shafts) with medium-coarse grained deposits. This might also indicate slightly higher-energy conditions in the case of the latter burrows. Moreover, in the lower and upper part of the middle Turonian section at Długopole Górne Quarry, Thalassinoides and Ophiomorpha are common. In the middle and upper part of the Długopole Górne section Ophiomorpha dominates (mostly as vertical burrows) and bivalves prevail (Fig. 11C-H). Other trace fossils, e.g., Asterosoma cf. Iudwigae, Curvolithus simplex, Phycodes cf. palmatus, Thalassinoides isp. (swollen chambers) appear in the uppermost part of this middle Turonian succession (Figs. 4 and 5A). In the upper part of the succession, trace fossils are more abundant (especially ophiomorids), than in its lower and middle part (Fig. 4), similar to the case of their equivalents in the Intra-Sudetic Synclinorium, the Radków Sandstones (cf. Jerzykiewicz and Wojewoda, 1986). This might suggest the greater hydrodynamic energy and a slightly shallower palaeonvironment during deposition of the upper part of the Długopole Górne deposits.

Sedimentation of these middle Turonian sandstones probably took place in a normal salinity and well-oxygenated environment. Asterosoma and Phycosiphon are regarded as trace fossils strongly associated with fully marine, stenohaline conditions (Bromley and Uchman, 2003; MacEachern and Gingras, 2007; Gingras et al., 2011), while Planolites, Ophiomorpha, Thalassinoides (so called facies-crossing ichnogenera) are also known from brackish conditions (mesohaline). Dactyloidites, though, has been regarded as a trace fossil typical of mesohaline settings (Agirrezabala and Gibert, 2004), but has also been reported from entirely marine environments (Wilmsen and Niebuhr, 2014a), similarly to Curvolithus (Buatois et al., 1998). Other burrows, such as ?Ancorichnus, Funalichnus and borings Entobia are commonly reported from open marine settings (El-Sabbagh, 2008; Pokorný, 2008; Luo et al., 2020). The moderately diverse trace fossil assemblage, comprising a variety of ethological categories, as well as the presence of common Thalassinoides point to a well-oxygenated environment (Buatois and Mángano, 2011; Gingras et al., 2011; Hofmann et al., 2011). Phycosiphon, though, is regarded as an indicator of low-oxygen conditions, when present in monospecific assemblages (Bromley and Ekdale, 1984; Baucon et al., 2020). In moderately to highly diverse ichnoassemblages this ichnotaxon usually occurs in well-oxygenated environments.

Asterosoma, Dactyloidites, Phycodes and Phycosiphon are evidence of an episodically nutrient-rich environment. The presence of both suspension- and deposit-feeders suggests availability of food in suspension and in the deposit (see Baucon and Neto de Carvalho, 2008). The occurrence of Planolites beverleyensis (the present study) and ?Macaronichnus (Chrząstek, 2013a) in Thalassinoides might suggest burrow fillings as additional food resources for some trace makers (cf. Rodríguez-Tovar, 2005; Łaska et al., 2017). Moreover, according to the authors cited, the darker colour of Ophiomorpha and Thalassinoides, than the host sediment, might be connected with the deposition of rusty layers during sedimentation of the sandstones or with growth of bacteria and algae on the burrow walls (see also Vlahović et al., 2011; Chrzastek, 2013a).

In summary, ichnological analysis, such as a moderately diverse trace fossil assemblage, moderate ichnodisparity (11 architectural designs), with sparse to common $(\mathrm{Bi}=0-4)$, commonly of low to moderate bioturbation $(\mathrm{BI}=2-3)$ and the presence of shallow- to mid-tier trace fossils produced mostly by deposit-feeders indicates a trace fossil assemblage characteristic of proximal to distal lower shoreface settings (Fig. 12). Sedimentation took place in a well-oxygenated, soft-ground, occasionally nutrient-rich basin with normal salinity under gentle to moderate hydrodynamic conditions, interrupted by more energetic conditions probably associated with more common or abundant sand supplies.

PALAEOECOLOGICAL SEDIMENTOLOGICAL AND PALAEOGEOGRAPHICALIMPLICATIONS

The associated bivalves, mostly suspension-feeders, especially oysters (e.g., Rhynchostreon), also suggest a shallow marine, well-oxygenated, nutrient-rich low to moderate energy setting (Dhondt et al., 1999; Seeling and Bengtson, 1999; Moussavou, 2017; Wetzel et al., 2020), up to 25-30 m deep (Schneider et al., 2011; Ayoub-Hannaa et al., 2014). Pinnids indicate mostly lower energy conditions (see Bengtson et al., 2014), e.g. in a lower shoreface setting (Carmona et al., 2020). The presence of brachiopods (cf. Chrząstek, 2013a) also indicates a normal salinity (stenohaline) environment.

The middle Turonian sandstones exposed in Długopole Górne Quarry, showing giant-scale cross-bedding, are proabably part of a progradational accumulation terrace deposited on fault-controlled scarps parallel to the Cretaceous palaeoshore (cf. Don and Wojewoda, 2004). The deposits studied are mainly structureless, but parallel lamination is locally observed (see also Don and Wojewoda, 2004). Other sedimentary structures, as hummocky cross-stratification, cross-stratification or ripple marks, were not observed. Moreover, a coarsening-upwards trend in the succession was also observed, especially in the southern part of Długopole Górne Quarry (cf. Jerzykiewicz and Wojewoda, 1986: fig. 5; Wojewoda, 1997; 


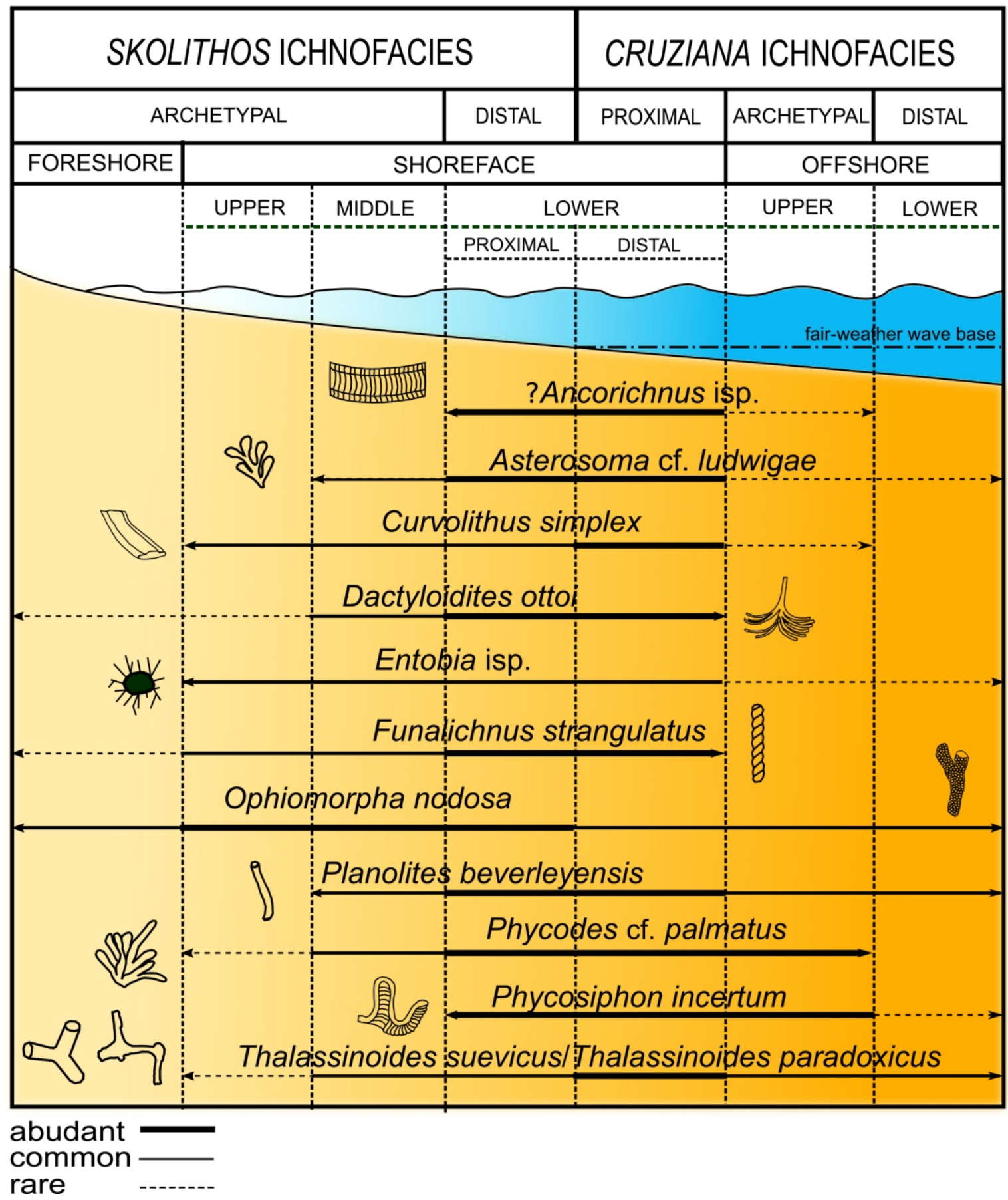

Fig. 12. Environmental distrubution of the trace fossil assemblage reported in the middle Turonian sandstones of Długopole Górne Quarry and in loose blocks located at Szklary and Wojsławice

(some details after Mayoral et al., 2013)

Fig. 5A). However, within the deposits studied, medium-grained sandstones prevail. The dominance of burrows characteristic of the Cruziana ichnofacies and lack of the trace fossils of suspension-feeding organisms, such as Skolithos, Arenicolites, Diplocraterion, Conichnus and escape traces (fugichnia), typical of the Skolithos ichnofacies support this interpretation and do not point to a storm orgin of these deposits (cf. Chrzastek, 2020). The sedimentary structures (giant-sale cross-lamination), coarsening-upwards trend of the succession, as well as the abundance of trace fossils in the upper part of the sandstones studied are in agreement with the hypothesis on the style of deposition suggested earlier by Jerzykiewicz and Wojewoda (1986), Wojewoda (1997) and Rotnicka (2005, see Ophiomorpha ichnofabric) for their counterparts in the Intra-Sudetic Basin (Radków Sandstones).

The coeval deposits of the adjacent Bohemian Cretaceous Basin, due to the presence of steep foreset packages, a coarsening-upwards trend and the dominance of coarse-grained deposits, were regarded recently as the deposits of coarse-grained Gilbert- or fan-type deltas (Uličný, 2001; Laurin and Uličný, 2004). This style of deposition was also suggested for the Coniacian deposits from the Bohemian Basin (see Uličný et al., 
2009). The deltaic origin of the equivalents from the Bohemian Basin seems to be doubtful for the deposits in Długopole Górne Quarry. The sedimentological pattern recorded in the Długopole Górne strata, e.g., predominance of fine- to medium-grained sandstones and lack of small scale trough cross-stratification (cf. Nadaskay and Uličný, 2014: fig. 7C) are not evidence of a Gilbert-delta origin of these sandstones (cf. Uličný, 2001; Laurin and Uličný, 2004). Though all trace fossils recorded in the deposits studied have been described from fanor Glibert-type deltas, e.g., Curvolithus, Ancorichnus, Phycosiphon, Phycodes, Ophiomorpha, Thalassinoides (see discussion in Hovikovski et al., 2019 and Chrząstek, 2020), the predominance of traces typical of the Cruziana ichnofacies, lack of fugichnia and other re-equilibration structures and high values of bioturbation index ( $\mathrm{BI}=0-4$, commonly $2-3)$, are not consistent with the high energy events characteristic for such a style of deposition (compare also MacEachern and Bann, 2020). In the coeval deposits from the Bohemian Cretaceous Basin, regarded as Gilbert-type facies, the values of bioturbation index are low (BI = 1-2) and monotypic trace fossil assemblages appear (cf. Laurin and Uličný, 2004). Moreover, gravelly sandstones, up to conglomeratic, often occur next to fine- to coarse-grained deposits, a pattern absent in the Polish part of the Late Cretaceous Basin (Upper Nysa Kłodzka Graben). Due to the lack of a small scale trough cross-stratification in these deposits, the other hypothesis suggested for the depositional environment of the sandy bodies from the Bohemian Basin, offshore bars, by Skoček and Valečka (1983), seems not to be appropriate for the sandstones from the Upper Nysa Kłodzka Basin.

The current study, especially the new trace fossils finds, supports the previous suggestion of Chrząstek (2013a) that sedimentation of the middle Turonion sandstones took place in a shallower environment, on the lower shoreface, than previously suggested, e.g., offshore or ?upper offshore (cf. Jerzykiewicz and Wojewoda, 1986; Don and Wojewoda, 2004; Rotnicka, 2005)

The ichnoassemblage studied shows close affinity in ichnotaxonomical composition to those of other adjacent Late Cretaceous basins, e.g Intra-Sudetic, North Sudetic (Poland), Bohemian and Saxonian (Czech Republic, Germany respectively; Fig. 1), though the different source areas (e.g., East or West Sudetic islands), and their independent tectonic activity, caused some differences in the evolution of their sedimentary successions (cf. Niebuhr and Seibertz, 2018). The succession studied is most similar in style of deposition to that of the Intra-Sudetic Basin (accumulation terraces), while in facies (sandy) to those of the Bohemian and Saxonian Cretaceous basins (Uličný, 2001; Janetschke and Wilmsen, 2014). Similar ichnotaxa, e.g., Palaeophycus, Ophiomorpha, Asterosoma, Thalassinoides and Phycosiphon were reported by Rotnicka (2005) from the middle Turonian of the Intra-Sudetic Basin, while Thalassinoides, Ophiomorpha, Planolites, Funalichnus are known from the equivalent deposits of the Bohemian Basin (Uličný, 2001; Laurin and Uličný, 2004; Pokorný, 2008). Moreover, trace fossils recorded in the middle Turonian sandstones have also been described from coeval deposits in the North Sudetic Basin and Saxonian Basin, e.g., Asterosoma, Ophiomorpha, Thalassinoides, Funalichnus, Dactyloidites, Planolites and the boring Entobia (cf. Niebuhr and Wilmsen, 2016). The trace fossils studied have also been reported from other Upper Cretaceous successions (upper TuronianConiacian) from the basins cited (Mikuláš, 2006; Leszczyński, 2010, 2018; Chrząstek and Wypych, 2018; Chrząstek, 2020).

Furthermore, associated body fossils reported from the current deposits, such as oysters (Rhynchostreon), pinnids, limids and rhynchonellid brachiopods have also been described from the middle Turonian of Germany, Saxony (Wilmsen and Niebuhr, 2014b), Bavaria (Wilmsen et al., 2007; Schneider et al., 2011, 2013) and the Czech Republic (Drahota, 1995; Tröger, 2003). The abundance of Rhynchostreon suborbiculatum (Fig. 12C, G, H, J) in the middle Turonian sandstones of Długopole Górne Quarry (Upper Nysa Kłodzka Graben) confirms the presence of Tethyan oysters also in Poland (North Temperate Realm).

\section{DISCUSSION AND CONCLUSIONS}

In the middle Turonian sandstones of Długopole Górne Quarry a moderately diverse trace fossil assemblage has been recognized, comprising burrows and borings ( 21 ichnospecies, 11 ichnogenera), some of them unknown earlier from the study area or from the Upper Nysa Kłodzka Graben (8, 5 respectively; Table 1). Fodinichnia or pascichnia/fodinichnia (Asterosoma cf. ludwigae, Asterosoma isp., Dactyloidites ottoi, Phycodes cf. palmatus, cf. Phycodes isp., Phycosiphon incertum, ?Phycosiphon isp., Planolites beverleyensis, Thalassinoides paradoxicus, Thalassinoides suevicus type $A$ and $B$ ) prevail in the assemblage. Domichnia or domichnia/fodinichnia are common (Ophiomorpha nodosa, Ophiomorpha isp., Funalichnus strangulatus), while pascichnia, pascichnia/repichnia and repichnia are rare (?Ancorichnus isp., Curvolithus simplex, respectively). Moreover, the boring Entobia and some associated body fossils, bivalves (?Brachidontes, Lima canalifera, Pinna cretacea, Rhynchostreon suborbiculatum), in the majority previously unknown from the study area, were also recorded.

The presence of Dactyloidites, Phycodes, Phycosiphon and Thalassinoides, typical of the Cruziana ichnofacies, indicates slow sedimentation under low energy hydrodynamic conditions. The presence of Ophiomorpha, which is characteristic of the Skolithos ichnofacies, might suggest slightly higher (moderate) energy conditions, probably associated with more abundant sand supplies (cf. Rotnicka, 2005).

The moderate ichnodiversity and ichnodisparity of the ichnoassemblage, with sparse to common bioturbation $(\mathrm{BI}=$ $0-4)$, commonly low to moderate $(\mathrm{BI}=2-3)$, indicates the proximal Cruziana ichnofacies, which characterizes the distal lower shoreface and the distal Skolithos ichnofacies typical of the proximal lower shoreface. The sedimentation took place in a shallow basin, well-oxygenated with normal salinity, occasionally rich in nutrients (e.g., Dactyloidites ottoi, Asterosoma cf. ludwigae, Phycodes cf. palmatus, Phycosiphon incertum), under low-moderate energy conditions, close to the fair-weather wave base. Accompanying body fossils, the oysters Rhynchostreon and pinnids Pinna (Pinna) cretacea, also point to a shallow-marine environment, up to 35-50 m deep.

Ichnological studies supports the sedimentological interpretations of these deposits by Jerzykiewicz and Wojewoda (1986) and Wojewoda (1997), in that these middle Turonian sandstones might be a part of a giant-scale cross-bedding accumulation terrace. The occurrence of coarser-grained sandstones and abundant ophiomorphid burrows in the upper part of the succession might suggest a shallowing-upwards trend.

Neither the ichnological nor the sedimentological analyses point to a storm origin for these deposits. Moreover, there is no evidence of their deltaic origin, suggested for their counterparts in the Bohemian Basin (see discussion in Uličný, 2001; Hovikoski et al., 2019; MacEachern and Bann, 2020).

The trace fossil assemblage shows most affinity in ichnotaxonomical composition to the equivalent assemblages from the Intra-Sudetic Basin and the Bohemian and Saxonian 
Cretaceous basins (Uličný, 2001; Rotnicka, 2005; Pokorný, 2008; Niebuhr and Wilmsen, 2016).

The study documents the occurrence of several bivalve (pinnids, oysters, limids) and brachiopod taxa (rhynchonellids), recorded earlier from coeval deposits of the Bohemian Basin, Bavaria and Saxony, indicating Tethyan influences in these regions.

Acknowledgements. The authors thank very much A. Uchman (Jagiellonian University, Poland), R. Pokorný (University J.E. Purkyně, Ústí nad Labem, Czech Republic),
A. Wetzel (University of Basel, Switzerland), M. Hyžný (Comenius University, Bratislava, Slovakia) and F. Muñiz (University of Sevilla, Spain) for discussions concerning some of the ichnotaxa distinguished. The reviewer S. Leszczyński (Jagiellonian University, Poland) is gratefully appreciated for all comments and suggestions. Thanks are also given to R. Niedźwiedzki (University of Wrocław) for providing two specimens to study and for some photographs and to K. Pluta for some figures. The authors thank $Z$. and R. Więcławek (PIASMAR Company, Szklary) for allowing the study of trace fossils in Długopole Górne Quarry.

\section{REFERENCES}

Abdelhady, A.A., 2009. Cenomanian/Turonian mass extinction of macroinvertebrates in the context of paleoecology. A case study from North Wadi Quena, Eastern Desert, Egypt. In: Mass Extinction (ed. A.M.T. Elewa): 103-127. Spinger-Verlag.

Agirrezabala, L.M., Gibert de, J.M., 2004. Paleodepth and paleoenvironment of Dactyloidites ottoi (Geinitz, 1849) from Lower Cretaceous deltaic deposits (Basque-Cantabrian Basin west Pyrenees). Palaios, 19: 276-291.

Aguirre, M.L. Perez, S.I., Sirch, Y.N., 2006. Morphological variability of Brachidontes Swainson (Bivalvia, Mytilidae) in the marine Quaternary of Argentina (SW Atlantic). Palaeogeography, Palaeoclimatology, Palaeoecology, 239: 100-125.

Alpert, S.P., 1975. Planolites and Skolithos from the Upper Precambrian-Lower Cambrian White-Inyo Mountains, California. Journal of Paleontology, 49: 509-521.

Anderson, B.G., Droser, M.L., 1998. Ichnofabrics and geometric configurations of Ophiomorpha within a sequence stratigraphic framework: an example from the Upper Cretaceous U.S. western interior. Sedimentology, 45: 379-396.

Archer, A.W., Maples, C.G., 1984. Trace fossil distribution across a marine-to-nonmarine gradient in the Pennsylvanian of southwestern Indiana. Journal of Paleontology, 58: 448-466.

Ayoub-Hannaa, W., Fürsich, F.T., 2011. Functional morphology and taphonomy of Cenomanian (Cretaceous) oysters from the eastern Sinai Peninsula, Egypt. Palaeobiodiversity and Palaeoenvironments, 91: 197-214.

Ayoub-Hannaa, W., Fürsich, F.T., El Qot, G.M., 2014. Cenomanian-Turonian bivalves from eastern Sinai, Egypt. Palaeontographica, Abteilung A: Paläozoologie-Stratigraphie, 301: 63-168.

Baucon, A., Neto de Carvalho, C., 2008. From the river to the sea: Pramollo, a new ichnolagerstätte from the Carnic Alps (Carboniferous, Italy-Austria). Studi Trentini di Science Naturali, Acta Geologica, 83: 87-114

Baucon, A., Bednarz, M., Dufour, S., Felletti, F., Malgesini, G., Neto de Carvalho, C., Niklas, K.J., Wehrmann, A., Batstone, R., Bernardini, F., Briguglio, A., Cabella, R., Cavalazzi, B. Ferretti, A., Zanzerl, H., Mcllroy, D., 2020. Ethology of the trace fossil Chondrites: form, function and environment. Earth-Science Reviews, 202; doi: 10.1016/j.erascirev.2019.102989

Bayet-Goll, A., Carvalho, C.N. de, Mahmudy-Gharaei, M.H. Nadaf, R., 2015. Ichnology and sedimentology of a shallow marine Upper Cretaceous depositional system (Neyzar Formation, Kopet-Dagh, Iran): palaeoceanographic influence on ichnodiversity. Cretaceous Research, 56: 628-646.

Bednarz, M., Mclroy, D., 2009. Three-dimensional reconstruction of "phycosiphoniform" burrows: Implications for identification of trace fossils in core. Palaeontologia Electronica, 12: 15

Belaústegui, Z., Domènech, R., Martinell, J., 2015. Trace fossils of the Middle Miocene of the El Camp de Tarragona Basin (NE Spain). Geological Association of Canada, Miscellaneous Publication, 9: 15-30.
Bengtson, P., Ayoub-Hannaa, W., Fürsich, F.T., Heinze, M., 2014. Taxonomy and palaeoecology of Pinna (P.) cretacea (Schlotheim, 1813) from the Upper Cretaceous of the Sergipe Basin, Brazil. Revista Brasileria de Paleontologia, 17: 289-306.

Biernacka, J., Józefiak, M., 2009. The Eastern Sudetic Island in the early-to-middle Turonian: evidence from heavy minerals in the Jerzmanice sandstones, SW Poland. Acta Geologica Polonica, 59: 545-565.

Billings, E., 1862. New species of Lower Silurian fossils. Geological Survey, Canada.

Bown, T.M., Kraus, M.J., 1983. Ichnofossils of the alluvial Willwood Formation (Lower Eocene), Bighorn basin, Northwest Wyoming U.S.A. Palaeogeography, Palaeoclimatology, Palaeoecology, 43: 95-128.

Boyd, C., Mcllroy, D., 2016. Three-dimensional morphology and palaeobiology of the trace fossil Dactyloidites jordii nov. isp. from the Carboniferous of England. Geobios, 49: 257-264.

Boyd, C., Mcllroy, D., 2017. Three-dimensional morphology of Beaconites capronus from northeast England. Ichnos, 24 250-258.

Boyd, C., Mcllroy, D., Herringshaw, L.G., Leaman, M., 2012. The recognition of Ophiomorpha irregulaire on the basis of pellet morphology: Restudy of material from the type locality. Ichnos, 19: $185-189$.

Bromley, R.G., 1996. Trace Fossils. Biology, Taphonomy and Applications. Chapman and Hall, London.

Bromley, R.G., Asgaard, U., 1993. Two bioerosion ichnofacies produced by early and late burial associated with sea level change. Geologische Rundschau, 82: 276-280.

Bromley, R.G., D'Alessandro, A., 1984. The ichnogenus Entobia from the Miocene, Pliocene and Pleistocene of southern Italy. Rivista Italiana di Paleontologia e Stratigrafia, 90: 227-296.

Bromley, R.G., Ekdale, A.A., 1984. Chondrites: a trace fossil indicator of anoxia in sediments. Science, 224: 872-874.

Bromley, R.G., Uchman, A., 2003. Trace fossils from the Lower and Middle Jurassic marginal marine deposits of the Sorthat Formation, Bornholm, Denmark. Bulletin of the Geological Society of Denmark, 52: 185-208.

Bromley, R.G., Milàn, J., Uchman, A., Hanken, K.S., 2009. Rheotactic Macaronichnus and human and cattle trackways in Holocene beachrock, Greece: Reconstruction of paleoshoreline orientation. Ichnos, 16: 103-117.

Bronn, H.G. 1837. Lethaea Geognostica, oder Abbildungen und Beschreibungen der für die Gebirgsformationen bezeichendsten Versteinerungen. 672 pp, Stuttgart (Schweizerbat).

Buatois, L.A., Mángano, M.G., 2011. Ichnology. Organism-Substrate Interactions in Space and Time. Cambridge University Press.

Buatois, L.A., Mángano, M.G., 2013. Ichnodiversity and ichnodisparity: significance and caveats. Lethaia, 46: 281-292. 
Buatois, L.A., Mángano, M.G., Mikuláš, R., Maples, C.G., 1998 The ichnogenus Curvolithus revisited. Journal of Paleontology, 72: 758-769.

Buatois, L.A., Wisshak, M., Wilson, M.A., Mángano, M.G., 2017. Categories of architectural designs in trace fossils: a measure of ichnodisparity. Earth-Science Reviews, 164: 102-181.

Carmona, N.B., Buatois, L.A., Mángano, M.G., Bromley, R.G. 2008. Ichnology of the Lower Miocene Chenque Formation, Patagonia, Argentina: animal-substrate interactions and the Modern Evolutionary Fauna. Ameghiniana, 45: 93-122.

Carmona, N.B., Mangano, M.G., Buatois, L.A., Bromley, R. Ponce, J.J., Asgaard, U., Bellosi, E., 2020. Scolicia and its producer in shallow-marine deposits of the Miocene Chenque Formation (Patagonia, Argentina): functional morphology and implications for understanding burrowing behavior. Ichnos, 27 290-299.

Chrząstek, A., 2012. Palaeontology of the Middle Turonian limestones of the Nysa Kłodzka Graben (Sudetes, SW Poland): biostratigraphical and palaeogeographical implications. Geologos, 18: 83-109.

Chrząstek, A., 2013a. Middle Turonian trace fossils from the Bystrzyca and Długopole sandstones in the Nysa Kłodzka Graben (Sudetes, SW Poland). Geological Quarterly, 57 (3): 443-466.

Chrząstek, A., 2013b. Trace fossils from the Lower Muschelkalk of Raciborowice Górne (North Sudetic Synclinorium, SW Poland) and their palaeoenvironmental interpretation. Acta Geologica Polonica, 63: 315-353.

Chrząstek, A., 2020. Palaeoenvironmental interpretation of the late Cretaceous Idzików Conglomerate Member (SW Poland Sudetes, Idzików Quarry) based on analysis of trace fossils. Annales Societatis Geologorum Poloniae, 90: 149-194.

Chrząstek, A., Pluta, K., 2017. Trace fossils from the Baltoscandian erratic boulders in SW Poland. Annales Societatis Geologorum Poloniae, 87: 229-257.

Chrząstek, A., Wojewoda, J., 2011. Mesozoic of South-Western Poland (The North Sudetic Synclinorium) (in Polish with English summary). In: Mezozoik i Kenozoik Dolnego Śląska (eds. A Żelaźniewicz, J. Wojewoda and W. Ciężkowski): 1-10. WIND Wrocław.

Chrząstek, A., Wypych, M., 2018. Coniacian sandstones from the North Sudetic Synclinorium revisited: palaeoenvironmental and palaeogeographical reconstructions based on trace fossil analysis and associated body fossils. Geologos, 24: 29-53.

Chrząstek, A., Muszer, J., Solecki, A., Sroka, A.M., 2018. Rosarichnoides sudeticus igen. et isp. nov. and associated fossils from the Coniacian of the North Sudetic Synclinorium (SW Poland). Geological Quarterly, 62 (1): 181-196.

Clifton, H.E., Thompson, J.K., 1978. Macaronichnus segregatis: A feeding structure of shallow marine polychaetes. Journal of Sedimentary Petrology, 48: 1293-1302.

Curran, H.A., 1985. The trace fossil assemblage of a Cretaceous nearshore environment. SEPM Special Publication, 35 261-276.

Cymerman, Z., 1997. Structure, kinematics and an evolution of the Orlica-Śnieżnik Dome, Sudetes (in Polish with English summary). Prace Państwowego Instytutu Geologicznego, 156.

Dahmer, G., 1937. Lebensspuren aus dem Taunusquarzit und den Siegener Schichten (Unterdevon). Preussischen Geologischen Landesanstalt zu Berlin Jahrbuch 1936, 57: 523-539.

Dam, G., 1990. Taxonomy of trace fossils from the shallow marine Lower Jurassic Neill Klinter Formation, East Greenland. Bulletin of the Geological Society of Denmark, 38: 119-144.

Dashtgard, S.E., Gingras, M.K., Pemberton, S.G., 2008. Grain-size controls on the occurrence of bioturbation. Palaeogeography, Palaeoclimatology, Palaeoecology, 257: 224-243.

Dashtgard, S.E., MacEachern, J.A., Frey, S.E., Gingras, M.K., 2012. Tidal effects on the shoreface: Towards a conceptual framework. Sedimentary Geology, 279: 42-61.

Demircan, H., 2012. Determination of a Late Miocene rocky palaeoshore by bioerosion trace fossils from the Bozcaada Is- land, Canakkale, Turkey. Comptes Rendus Palevol, 11: 331-344.

Desai, B.G., Saklani, R.D., 2014. Ichnofabric analysis of the Tithonian shallow marine sediments (Bhadasar Formation) Jaisalmer Basin, India. Journal of Earth System Science, 123 1413-1431.

Dhondt, A.V., Malchus, N., Boumaza, L., Jaillard, E., 1999. Cretaceous oysters from North Africa: origin and distribution. Bulletin de la Société géologique de France, 170: 67-76.

Don, B., Don, J., 1960. Notes on the origin of the Nysa Graben (in Polish with English summary). Acta Geologica Polonica, 10: 71-106.

Don, J., Gotowała, R., 2008. Tectonic evolution of the late Cretaceous Nysa Kłodzka Graben, Sudetes, SW Poland. Geologica Sudetica, 40: 51-63.

Don, J., Wojewoda, J., 2004. Tectonics of upper Nysa Kłodzka Graben - controversial issues (in Polish with English summary). Przegląd Geologiczny, 52: 883-886

Don, J., Wojewoda, J., 2005. Tectonics of upper Nysa Kłodzka Graben - controversial issues - reply (in Polish). Przegląd Geologiczny, 53: 212-221.

Drahota, P., 1995. Rhynchostreon suborbiculatum (Lamarck) a jeho výskyt v kolĺnské oblasti české křldové tabuli (in Czech). Bohemia centralis, 24: 5-16.

Dworschak, P.C., Rodrigues, S. de, 1997. A modern analogue for the trace fossil Gyrolithes: burrows of the thalassinidean shrimp Axianassa australis. Lethaia, 30: 41-52.

Ehrenberg, K., 1944. Ergänzende Bemerkungen zu den seinerzeit aus dem Miozän von Burgschleinitz beschrieben Gangkernen und Bauten dekapoder Krebse. Paläontologische Zeitschrift, 23: 345-359.

Ekdale, A.A., Bromley, R.G., 2003. Paleoethologic interpretation of complex Thalassinoides in shallow-marine limestones, Lower Ordovician, southern Sweden. Palaeogeography, Palaeoclimatology, Palaeoecology, 192: 221-227.

Ekdale, E.G., Ekdale, A.A., 2018. Hillichnus lobosensis, an unusually complex trace fossil of burrowing bivalves from the Paleogene of southern California, U.S.A. Palaeogeography, Palaeoclimatology, Palaeoecology, 493: 119-125.

El-Hedeny, M., El-Sabbagh, A., 2018. Entobia ichnofacies from the Middle Miocene carbonate succession of the northern Western Desert of Egypt. Annales Societatis Geologorum Poloniae, 88: $1-19$.

El-Sabbagh, A.M., 2008. Biostratigraphy, taphonomy and palaeoecology of two tropical Coniacian-Santonian oyster species from Wadi Sudr, western Sinai, Egypt. Neues Jahrbuch für Geologie und Paläontologie, Abhandlungen, 249: 47-74.

El-Sabbagh, A., El-Hedeny, M., Al Farraj, S., 2017. Thalassinoides in the Middle Miocene succession at Siwa Oasis, northwestern Egypt. Proceedings of the Geologists' Association, 128: 222-233.

Feng, X., Chen, Z.-Q., Woods, A., Fang, Y., 2017. A Smithian (Early Triassic) ichnoassemblage from Lichuan, Hubei Province, South China: Implications for biotic recovery after the latest Permian mass extinction. Palaeogeography, Palaeoclimatology, Palaeoecology, 486: 123-141.

Fillion, D., Pickerill, R.K., 1990. Ichnology of the Cambrian? To Lower Ordovician Bell Island and Wabana groups of eastern Newfoundland, Canada. Palaeontographica Canadiana, 7: $1-119$.

Fischer-Ooster, C., 1858. Die fossilien Fucoiden der Schweizer Alpen, nebst Erörterungen über deren geologisches Alter. Huber, Bern

Fistek, J., Gierwielaniec, J., 1964. Objaśnienia do szczegółowej mapy geologicznej Sudetów, Arkusz Bystrzyca Nowa w skali 1:25 000 (in Polish). Instytut Geologiczny, Wyd. Geol., Warszawa.

Fitch, A., 1850. A historical, topographical and agricultural survey of the County of Washington. Part 5. New York Agricultural Sciety, Transactions, 9 (1849): 753-944. 
Frey, R.W., Howard, J.D., 1981. Conichnus and Schaubcylindrichnus: redefined trace fossils from the Upper Cretaceous of the Western Interior. Journal of Paleontology, 55: 800-801.

Frey, R.W., Howard, J.D., 1985. Trace fossils from the Panther Member, Star Point Formation (Upper Cretaceous), Coal Creek Canyon, Utah. Journal of Paleontology, 59: 370.

Frey, R.W., Seilacher, A., 1980. Uniformity in marine invertebrate ichnology. Lethaia, 13: 183-207.

Frey, R.W., Curran, H.A., Pemberton, S.G., 1984a. Tracemaking activities of crabs and their environmental significance: the ichnogenus Psilonichnus. Journal of Paleontology, 58: 333-350.

Frey, R.W., Howard, J.D., Pryor, W.A., 1978. Ophiomorpha: Its morphologic, taxonomic, and environmental significance. Palaeogeography, Palaeoclimatology, Palaeoecology, 23: 199-229.

Frey, R.W., Pemberton, S.G., Fagerstrom, J.A., 1984b. Morphological, ethological, and environmental significance of the ichnogenera Scoyenia and Ancorichnus. Journal of Paleontology, 58: $511-528$

Fritsch, A., 1883. Studien im Gebiete der böhmischen Kreideformation. Paläontologische Untersuchungen der einzelnen Schichten. III. Die Izerschichten. Archiv der naturwissenschaftlichen Landesdurchforschung von Böhmen. Band V, Nr 2, Comissions-Verlag von František Řivnáč. Prague.

Fritsch, A., 1908. Problematica Silurica. Systême Silurien du Centre de la Bohême par Joachim Barrande Suite Éditée-aux Frais du Barrande Fonds, Prague.

Fürsich, F.T., 1973. A revision of the trace fossils Spongeliomorpha, Ophiomorpha and Thalassinoides. Neues Jahrbuch für Geologie und Paläontologie, Monatshefte, 12: 719-735.

Fürsich, F.T., Bromley, R.G., 1985. Behavioural interpretation of a rosetted spreite trace fossil: Dactyloidites ottoi (Geinitz). Lethaia, 18: 199-207.

Fürsich, F.T., Uchman, A., Alberti, M., Pandey, D.K., 2018. Trace fossils of an amalgamated storm-bed succession from the Jurassic oft he Kachchh Basin, India: the significance of time-averaging in ichnology. Journal of Palaeogeography (Biopalaeogeography and palaeoecology), 7: 14-31 (00135).

Geinitz, H.B., 1839. Charakteristik der Schichten und Petrefacten des sächsisch-böhmischen Kreidegebirges (ed. H.B. Geinitz, 1839-1942). Arnoldi, Dresden \& Leipzig.

Geinitz, H.B., 1842. Die sächsisch-böhmische Schweiz, die Oberlausitz und das Innere von Böhmen. In: Charakteristik der Schichten und Petrefacten des sächsisch-böhmischen Kreidegebirges (ed. H.B. Geinitz). Drittes Heft. Der Arnoldischen Buchhandlung. Dresden und Leipzig. 1. Auflage: 63-116.

Geinitz, H.B., 1849. Das Quadersandsteingebirge ode Kreidegebirge in Deutschland. Graz and Gerlach, Freiberg.

Giannetti, A., Monacom P., Caracuel, J.E., Soria, J.M., Yébenes, A., 2007. Functional morphology and ethology of decapod crustaceans gathered by Thalassinoides branched burrows in Mesozoic shallow water environments. Memorie della Societa Italiana di Scienze Naturali e del Museo Civico di Storia Naturale di Milano, 35: 48-52.

Gibert, J.M. de, Ekdale, A.A., 2010. Paleobiology of the crustacean trace fossil Spongeliomorpha iberica in the Miocene of southeastern Spain. Acta Palaeontologica Polonica, 55: 733-740.

Gibert, J.M. de, Domènech, R., Martinell, J., 2007. Bioerosion in shell beds from the Pliocene Roussillon Basin, France: implications for the (macro) bioerosion ichnofacies model. Acta Palaeontologica Polonica, 52: 783-798.

Gibert, J.M. de, Martinell, J., Domènech, R., 1995. The rosetted feeding trace fossil Dactyloidites ottoi (Geinitz) from the Miocene of Catalonia. Geobios, 28: 769-776.

Gibert, J.M. de, Martinell, J., Domènech, R., 1998. Entobia ichnofacies in fossil rocky shores, Lower Pliocene, northwestern Mediterranean. Palaios, 13: 476-487.

Gingras, M.K., MacEachern, J.A., Dashtgard, S.E., 2011. Process ichnology and the elucidation of physico-chemical stress. Sedimentary Geology, 237: 115-134.
Glocker, E.F., 1841. Ueber die Kalkfuhrende Sandsteinformation auf beiden Seiten der mittleren March, in der Gegend zwischen Kwassitz und Kremsier. Academia Caesarea LeopoldinoCarolina Germanica Naturae Curiosorum, 19 (Supplement 2): 309-334.

Głuszek, A., 1998. Trace fossils from the Late Carboniferous storm deposits, Upper Silesia Coal Basin, Poland. Acta Palaeontologica Polonica, 43: 517-546.

Goldfuss, G.A., 1836. Petrefacta Germaniae, tam ea, Quae in Museo Universitatis Regiae Borussicae Fridericiae Wilhelmiae Rhenanea, serventur, quam alia quaecunque in Museis Hoeninghusiano Muensteriano aliisque, extant, iconibus et descriiptionns illustrate. Divisio quarta. Molluscorum acephalicorum reliquiae. I: 65-286. Bivalvia, Düsseldorf.

Goldring, R., Pollard, J.E., 1995. A re-evaluation of Ophiomorpha burrows in the Wealden Group (Lower Cretaceous) of southern England. Cretaceous Research, 16: 665-680.

Hall, J., 1847. Palaeontology of New York, 1. C. Van Benthuysen, Albany.

Hall, J., 1852. Palaeontology of New York, 2. C. Van Benthuysen, Albany.

Hall, J., 1886. Note on some obscura organisms in the roofing slate of Washington County, New York. Trustees New York State Museum of Natural History, Annual Report, 39.

Hammersburg, S.R., Hasiotis, S.T., Robison, R.A., 2018 Ichnotaxonomy of the Cambrian Spence Shale Member of the Langston Formation, Wellsville Mountains Northern Utah, USA Paleontological Contributions, 20: 1-66.

Han, Y., Pickerill, R.K., 1994. Phycodes templus isp. nov. from the Lower Devonian of northwestern New Brunswick, eastern Canada. Atlantic Geology, 30: 37-46.

Häntzschel, W., 1975. Trace fossils and problematica. In: Treatise on Invertebrate Paleontology, Part W, Miscellanea. Supplement I (ed. C. Teichert). Geological Society of America, Boulder-Colorado and University of Kansas; Lawrence-Kansas.

Heer, O., 1865. Die Urwelt der Schweiz. Friedrich Schultez, Zürich.

Heer, O., 1877. Flora fossils Helvetiae. Die vorweltliche Flora der Schweiz. J. Wurster \& Co., Zürich

Heinberg, C., 1974. A dynamic model for a meniscus filled tunnel (Ancorichnus $\mathrm{n}$. ichnogen.) from the Jurassic Pecten Sandstone of Milne Land, East Greenland. Rapport-Groenlands Geologiske Undersoegelse, 62: 1-20.

Heinberg, C., Birkelund, T., 1984. Trace-fossil assemblages and basin evolution of the Vardeklirft Formation (Middle Jurassic, Central East Greenland). Journal of Paleontology, 58: 362-397.

Herkat, M., 2007. Application of correspondence analysis to palaeobathymetric reconstruction of Cenomanian and Turonian (Cretaceous) rocks of Eastern Algeria. Palaeogeography, Palaeoclimatology, Palaeoecology, 254: 583-605.

Hoffmann, R., Grimmberger, G., 2011. Cone-like Organic and Inorganic Structures in Lower Cambrian Sandstone Geschiebes of Northern Germany. Archiv für Geschiebekunde 6: 73-124.

Hofmann, R., Goudemand, N., Wasmer, M., Büchner, H. Hautmann, M., 2011. New trace fossil evidence for an early recovery signal in the aftermath of the end-Permian mass extinction. Palaeogeography, Palaeoclimatology, Palaeoecology, 310 216-226.

Hovikoski, J., Uchman, A., Alsen, P., Ineson, J., 2019. Ichnological and sedimentological characterists of submarine fan-delta deposits in a half-graben, Lower Cretaceous palnatokes Bjerg Formation, NE Greenland. Ichnos, 26: 28-57.

Howard, J.D., Frey. R.W., 1984. Characteristic trace fossils in nearshore to offshore sequences, Upper Cretaceous of east-central Utah. Canadian Journal of Earth Sciences, 21: 200-219.

Hyžný, M., Duane, M.J., Reinink-Smith, L.M., Eastoe, C. Hudáčková, N., 2018. Taphonomy of ghost shrimps (Decapoda: Axiidea: Callianassidae) associated with their burrows within a middle Miocene mud volcano complex of Persian (Arabian) Gulf, Kuwait. Palaeogeography, Palaeoclimatology, Palaeoecology, 511: 218-231. 
Hyžný, M., Šimo, V., Starek, D., 2015. Ghost shrimps (Decapoda Axiidea: Callianassidae) as producers of an Upper Miocene trace fossil association from sublittoral deposits of Lake Pannon (Vienna Basin, Slovakia). Palaeogeography, Palaeoclimatology, Palaeoecology, 425: 50-66.

Izumi, K., 2015. Composite Phymatoderma from Neogene deep-marine deposits in Japan: implications for Phanerozoic benthic interactions between burrows and the trace-makers of Chondrites and Phycosiphon. Acta Palaeontologica Polonica, 60: 1009-1020.

Janetschke, N., Wilmsen, M., 2014. Sequence stratigraphy of the lower Upper Cretaceous Elbtal Group (Cenomanian-Turonian of Saxony, Germany). Zeitschrift der Deutschen Gesellschaft für Geowissenschaften, 165: 179-208.

Janetschke, N., Niebuhr, B., Wilmsen, M., 2015. Inter-regional sequence stratigraphical synthesis of the Planerkalk, Elbtal and Danubian Cretaceous groups (Germany): CenomanianTuronian correlations around the Mid-European Island. Cretaceous Research, 56: 530-549.

Jerzykiewicz, T., Wojewoda, J., 1986. The Radków and Szczeliniec sandstones: An example of giant foresets on a tectonically controlled shelf of the Bohemian Cretaceous Basin (Central Europe). Canadian Society of Petroleum Geologists, Memoir II: 1-15.

Jin, J., Harper, D.A., Rasmussen, J.A., Sheehan, P.M., 2012. Late Ordovician massive-bedded Thalassinoides ichnofacies along the palaequator of laurentia. Palaeogeography, Palaeoclimatology, Palaeoecology, 367-368: 73-88.

Keighley, D.G., Pickerill, R.K., 1994. The ichnogenus Beaconites and its distinction from Ancorichnus and Taenidium. Palaeontology, 37: 305-337.

Keighley, D.G., Pickerill, R.K., 1995. The ichnotaxa Palaeophycus and Planolites: historical perspectives and recommendations. Ichnos, 3: 301-309.

Kennedy, W.J., 1967. Burrows and surface traces from the Lower Chalk of southern England. Bulletin of the British Museum (Natural History). Geology, 15: 125-167.

Knaust, D., 2004. Cambro-Ordovician trace fossils from the SW-Norwegian Caledonides. Geological Journal, 39: 1-4.

Knaust, D., 2007. Invertebrate trace fossils and ichnodiversity in shallow-marine carbonates of the German Middle Triassic (Muschelkalk). SEPM Special Publication, 88: 221-238.

Knaust, D., 2015. Siphonichnidae (new ichnofamily) attributed to the burrowing activity of bivalves: ichnotaxonomy, behavior and palaeoenvironmental implications. Earth-Science Reviews, 150: $497-519$.

Knaust, D., 2017. Atlas of Trace Fossils in Well Core: Appearance, Taxonomy and Interpretation. Springer.

Knaust, D., 2019. The enigmatic trace fossil Tisoa de Serres, 1840 Earth-Science Reviews, 188: 123-147.

Knaust, D., 2020a. The paradoxical ichnotaxonomy of Thalassinoides paradoxicus: a name of different meanings. Paläontologische Zeitschrift; https://doi.org/10.1007/s12542-020-00520-z

Knaust, D., 2020b. Invertebrate coprolites and cololites revised. Papers in Palaeontology: 1-39, doi: 10.1002/spp2.1297

Komuda, J., Don, J., 1964. On the brachyanticline in Bystrzyca Kłodzka (Sudetes Mts., Poland) (in Polish with English summary). Acta Geologica Polonica, 14: 169-174.

Lamarck, J.B.P.A. de, 1801. Système des Animaux sans Vertèbres, ou tableau général des classes, des orders et des genres de ces animaux, etc. Déterville, Paris.

Laurin, J., Uličný, D., 2004. Controls on a shallow-water hemipelagic carbonate system adjacent to a siliciclastic margin example from Late Turonian od Central Europe. Journal of Sedimentary Research, 74: 697-717.

Leaman, M., Mcllroy, D., Herringshaw, L.G., Boyd, C., Callow, R.H., 2015. What does Ophiomorpha irregulaire really look like? Palaeogeography, Palaeoclimatology, Palaeoecology, 439: $38-49$.

Leszczyński, S., 2010. Coniacian-Santonian paralic sedimentation in the Rakowice Małe area of the North Sudetic Basin, SW Poland: sedimentary facies, ichnological record and palaeo- geographic reconstruction of an evolving marine embayment. Annales Societatis Geologorum Poloniae, 80: 1-24.

Leszczyński, S., 2018. Integrated sedimentological and ichnological study of the Coniacian sedimentation in North Sudetic Basin. Geological Quarterly, 62 (4): 767-816.

Lissón, C.I., 1904. Los Tigillites des Salto del Fraile y algunas Sonneratia del Morro Solar. Boletí́n del Cuerpe de Ingenieros de Minas del Perú, 17: 5-64.

Lockley, M.G., Rindsberg, A.K., Zeiler, R.M., 1987. The paleoenvironmental significance of the nearshore Curvolithus ichnofacies. Palaios, 2: 255-262.

López Cabrera, M.I., Olivero, E.B., 2014. Ophiomorpha irregulaire and associated trace fossils from the Upper Cretaceous of Patagonia, Argentina: palaeogeographical and ethological significance. Spanish Journal of Palaeontology, 29: 33-44.

Löwermark, L., Hong, E., 2006. Schaubcylindrichnus formosus isp. nov. in Miocene sandstones from northeastern Taiwan. Ichnos, 13: 267-276.

Lundgren, B., 1891. Studier öfver fossiliförande lösa block. Geologiska Föreningens Stockholm Förhandlingar, 13: 111-121.

Luo, M., Shi, G.R., Buatois, L.A., Zhong-Qiang, C. 2020. Trace fossil as proxy for biotic recovery after the end-Permian mass extinction: a critical review. Earth-Science Reviews, 203, doi.org/10.1016/j.earscirev.2019.103059

Łaska,W., Rodríguez-Tovar, F.J., Uchman, A., 2017. Evaluating microbenthic response to the Cretaceous-Palaeogene event: a high-resolution ichnological approach at the Agost section (SE Spain). Cretaceous Research, 70: 96-110.

MacEachern, J.A., Bann, K., 2008. The role of ichnology in refining shallow marine facies models. SEPM Special Publication, $\mathbf{9 0}$ 73-116.

MacEachern, J.A., Bann, K.L., 2020. The Phycosiphon Ichnofacies and the Rosselia Ichnofacies: two new ichnofacies for marine deltaic environments. Journal of Sedimentary Research, 90: 855-886.

MacEachern, J.A., Gingras, M.K., 2007. Recognition of brackish-water trace-fossil suites in the Creataceous Western Interio Seaway of Alberta, Canada. SEPM Special Publication, 88: 149-193.

MacEachern, J.A., Zaitlin, B.A., Pemberton, S.G., 1999. A sharp-based sandstone of the Viking Formation, Joffre Field, Alberta, Canada: criteria for recognition of transgressively incised shoreface complexes. Journal of Sedimentary Research, 69: 876-89.

MacEachern, J.A., Pemberton, S.G., Gingras, M.K., Bann, K.L., 2007. The ichnofacies paradigm: a fifty-year retrospective. In Trace Fossils, Concepts, Problems, Prospects (ed. W. Miller, III): 52-77. Elsevier, Amsterdam.

MacEachern, J.A., Bann, K.L., Gingras, M.K., Zonneveld, J.-P., Dashtgard, S.E., Pemberton, S.G., 2012. The ichnofacies paradigm. Developments in Sedimentology, 64: 103-138.

Mángano, M.G., Buatois, L.A., 2016. The Cambrian explosion. Topics in Geobiology, 39: 71-126.

Maples, C.G., Suttner, L.J., 1990. Trace fossils and marine-nonmarine cyclicity in the Fountain Formation (Pennsylvanian: Morrowian/Atokan) near Manitou Springs, Colorado. Journal of Paleontology, 64: 859-880.

Mayoral, E., Ledesma-Vazquez, J., Baarli, B.G., Santos, A., Ramalho, R., Cachăo, M., Silva, C.M. da, Johnson, M.E., 2013. Ichnology in oceanic islands; case studies from the Cape Verde Archipelago. Palaeogeography, Palaeoclimatology, Palaeoecology, 381-382: 47-66.

Mikuláš, R., 2000. Trace fossils from the Cambrian of the Barandian area. Czech Geological Survey, Special Papers, 12: 1-29.

Mikuláš, R., 2006. Ichnofabric and substrate consistency in Upper Turonian carbonates of the Bohemian Cretaceous Basin Geologica Carpathica, 57: 79-90.

Morton, B. Leung, P.T.Y., Wei, J., Lee, G.Y., 2020. Morphological and genetic comparison of Septifer bilocularis, Mytilisepta virgate and Brachidontes variabilis (Bivalvia: Mytiloidea) from Hong Kong and 
erection of the Mytiliseptiferinae sub-fam. nov. Regional Studies in Marine Science, 34, doi.org/10.1016/j.rsma.2019.100981

Moussavou, B.M., 2017. Systematics, palaeoecology and taphonomy of Turonian oysters from the northern Gabon Coastal Basin. Geodiversitas, 39: 213-224.

Muñiz, F., Mayoral, E., 2001. Macanopsis plataniformis nov. ichnosp. from the Lower Cretaceous and Upper Miocene of the Iberian Peninsula. Geobios, 34: 91-98.

Muñoz, D.F., Mángano, M.G., Buatois, L.A., 2019. Gyrophyllites cristinae isp. nov. from Lower Ordovician shallow-marine deposits of northwest Argentina. Ichnos, 26: 243-255.

Myrow, P.M., 1995. Thalassinoides and the enigma of Early Paleozoic open-framework burrow systems. Palaios, 10: 58-74.

Nádaskay, R., Uličný, D., 2014. Genetic stratigraphy of Coniacian deltaic deposits of the northwestern part of the Bohemian Cretaceous Basin. Zeitschrift der Deutschen Gesellschaft für Geowissenschaften, 165: 547-575.

Nagm, R., Boualem, N., 2019. First documentation of the late Albian transgression in northwest Algeria: Bivalve stratigraphy and palaeobiogeography. Cretaceous Research, 93: 197-210.

Nara, M., Seike, K., 2019. Palaeoecology of Macaronichnus segregatis degiberti: Reconstructing the infaunal lives of the travisiid polychaetes. Palaeogeography, Palaeoclimatology, Palaeoecology, 516: 284-294

Naruse, H., Nifuku, K., 2008. Three-dimensional morphology of the ichnofossil Phycosiphon incertum and its implication for paleoslope inclination. Palaios, 23: 270-279.

Neto de Carvalho, C., Rodrigues, N.P.C., 2007. Compound Asterosoma ludwigae Schlirf, 2000 from the Jurassic of the Lusitanian Basin (Portugal); conditional strategies in the behaviour of Crustacea. Journal of Iberian Geology, 33: 295-310.

Neto de Carvalho, C. de, Rodrigues, N.P.C., Viegas, P.A., Baucon, A., Santos, V.K., 2010. Patterns of occurrence and distribution of crustacean ichnofossils in the Lower Jurassic Upper Cretaceous of Atlantic occidental margin basins, Portugal. Acta Geologica Polonica, 60: 19-28.

Neto de Carvalho, C., Viegas, P.A., Cachăo, M., 2007. Thalassinoides and its producer: populations of Mecochirus buried within their burrow systems, Boca do Chapim Formation (Lower Cretaceous), Portugal. Palaios, 22: 107-112.

Nicholson, H.A., 1873. Contributions to the study of the erran annelids of the older Palaeozoic rock. Proceedings of the Roya Society of London, 21: 288-290.

Niebuhr, B., Seibertz, E., 2018. Comptoniaster michselisi nom. nov. (Asteroidea, Goniasteridae): Revision of a starfish species from the lower Upper Cretaceous of central Europe previously described as Pentagonaster semilunatus and Asterias schulzii. Cretaceous Research, 87: 126-144.

Niebuhr, B., Wilmsen, M., 2016. 16. Ichnofossils. Geologia Saxonica, 62: 181-238.

Niedźwiedzki, R., Salamon, M., 2005. Late Cretaceous crinoids from the Sudetes (southern Poland). Freiberger Forschungshefte, C 507: 1-9.

Olivero, E.B., López-Cabrera, M.I., 2020. A new shallow-marine, high-latitude record oft he trace fossil Macaronichnus in Miocene, reworked delta-front clinoforms, Punta Basilica, Tierra Del Fuego, Argentina. Ichnos, doi: 10.1080/10420940.2020.1755854

Otto, E. von, 1854. Additamente zur Flora des Quadergebirges in Sachsen. Heft 2., G. Mayer Leipzig.

Patel, S.J., Desai, B.G., Vaidya, A.D., Shukla, R., 2008. Middle Jurassic from Habo Dome, Main Land Kachchh, Western India. Journal of Geological Society of India, 71: 345-362.

Pemberton, S.G., Frey, R.W., 1982. Trace fossil nomenclature and the Planolites-Palaeophycus dilemma. Journal of Paleontology, 56: 843-881.

Pemberton, S.G., Spila, M., Pulham, A.J., Saunders, T., MacEachern, J.A., Robbins, D., Sinclair, I.K., 2001. Ichnology \& sedimentology of shallow to marginal marine systems. Ben Nevis \& Avalon Reservoirs, Jeanne d'Arc Basin. Short Course Notes, 15: 1-343.

Pemberton, S.G., MacEachern, J.A., Dashtgard, S.E., Bann, K.L., Gingras, M.K., Zonneveld, J.-P., 2012. Shorefaces. Developments in Sedimentology, 64: 563-603.
Pervesler, P., Uchman, A., 2004. Ichnofossils from the type area of the Grund Formation (Miocene, Lower Badenian) in northern Lower Austria (Molasse Basin). Geologica Carpathica, 55 103-110.

Pervesler, P., Roetzel, R., Uchman, A., 2011. Ichnology of shallow sublittoral siliclastics of the Burgschleinitz Formation (Lower Miocene, Eggenburgian) in the Alpine-Carpathian Foredeep (NE Austria). Austrian Journal of Earth Science, 104: 91-96.

Pickerill, R.K., Donovan, S.K., Dixon, H.L., 1993. The trace fossil Dactyloidites ottoi (Geinitz, 1849) from the Neogene August Town Formation of south-central Jamaica. Journal of Paleontology, 67: 1070-1074.

Pineda-Salgado, G., Quiroz-Barroso, S.A., Sour-Tovar, F., 2015. Analysis of bioerosion in clasts from a Miocene rocky-shore, Concepción Formation, Veracruz, México. Palaeogeography, Palaeoclimatology, Palaeoecology, 439: 50-62.

Phillips, C., Mcllroy, D., Elliott, T., 2011. Ichnological characterization of Eocene/Oligocene turbidites from the Gres d'Annot Basin, French Alps, SE France. Palaeogeography, Palaeoclimatology, Palaeoecology, 300: 67-83.

Pokorný, R., 2008. Funalichnus, a new ichnogenus and its type ichnospecies Funalichnus strangulatus (Fritsch 1883), Upper Cretaceous of the Bohemian Cretaceous Basin, Czech Republic. Ichnos, 15: 51-58.

Pokorný, R., Bažant, Z., 2011. Ichnological research of the Upper Cretaceous sediments near Bartošovice v Orl. horách (Rychnov and Knežnou district). Acta Musei Richnoviensis, 18: 1-8.

Pollard, J.E., Goldring, R., Buck, S.G., 1993. Ichnofabrics containing Ophiomorpha: significance in shallow-water facies interpretation. Journal of the Geological Society, 150: 149-164.

Quatrefages, M. A. de, 1849. "Note sur la Scolicia prisca (A. de Q.), annelide fossile de la craie." Annales des Sciences Naturelles 3 , Zoologie, 12: 265-266.

Quenstedt, F.A., 1879. Petrefactenkunde Deutschlands. Korallen (Sternkorallen). Erste Abtheilung, Sechster Band, Drittes Heft, Atlas: 337-496. Fues's Verlag (R. Reisland), Leipzig.

Radwański, S., 1965. Geology of the Nysa Graben in the vicinity of Bystrzyca Kłodzka and Długopole Dolne (in Polish with English summary). Biuletyn Instytutu Geologicznego, 185: 229-242.

Radwański, S., 1975. Upper Cretaceous of the central part of the Sudetes in the light of new borehole materials (in Polish with English summary). Biuletyn Instytutu Geologicznego, 287: 5-59.

Rajkonwar, C., Lalramengi Fanai, J., Malsawma, P., Lalnuntluanga, C., Lalremruatfela, C., Tiwari, R.P., 2015. Ichnofossil assemblage of Bhuban Formation (Surma Group) from Zuangtui area, Aizawl, Mizoram. Science Vision, 25: 164-177.

Richardt, N., Wilmsen, M., Niebuhr, B., 2013. Late Cenomanian-Early Turonian facies development and sea-level changes in the Bodenwöhrer Senke (Danubian Cretaceous Group, Bavaria, Germany). Facies, 59: 803-827.

Richter, R., 1937. Marken und Spuren aus alten Zeiten I-II. Senckenbergiana, 19: 150-178.

Richter, R., 1850. Aus der thuringischen Grauwacke. Zeitschrift der Deutschen Geologischen Gesellschaft, 2: 198-206.

Rieth, A., 1932. Neue Funde spongeliomorpher Fucoiden aus Jura Schwabens. Geologische Paläontologische Abhandlungen, Neue Folge, 19: 257-294.

Rindsberg, A.K., 2018. Ichnotaxonomy as a science. Annales Societatis Geologorum Poloniae, 88: 91-110.

Rindsberg, A.K., Martin, A. J., 2003. Arthrophycus in the Silurian of Alabama (USA) and the problem of compound trace fossils. Palaeogeography, Palaeoclimatology, Palaeoecology, 192: 187-219.

Rodríguez-Tovar, F.J., 2005. Fe-oxide spherules infilling Thalassinoides burrow at the Cretaceous-Paleogene (K-Pg) boundary: evidence of a near-contemporaneous microbenthic colonization during the K-Pg event. Geology, 33: 585-588.

Rodríguez-Tovar, F.J., Aguirre, J., 2014. Is Macaronichnus an exclusively small, horizontal and unbranched structure? Macaronichnus segregatis degiberti isubsp. nov. Spanish Journal of Palaeontology, 29: 131-142. 
Rodríguez-Tovar, F.J., Nagy, J., Reolid, M., 2014a Palaeoenvironment of Eocene prodelta in Spitsbergen recorded by the trace fossil Phycosiphon incertum. Polar Research, 33 23786.

Rodríguez-Tovar, F.J., Stachacz, M., Uchman, A., Reolid, M., 2014b. Lower/Middle Ordovician (Arenigian) shallow-marine trace fossils of the Pochico Formation, southern Spain: palaeoenvironmental and palaeogeographic implications at the Gondwanan and peri-Gondwanan realm. Journal of Iberian $\mathrm{Ge}$ ology, 40: 539-555.

Rodríguez-Tovar, F.J., Dorador, J., Mayoral, E., Santos, A., 2017. Outcrop and core integrative ichnofabric analysis of Miocene sediments from Lepe, Huelva (SW Spain): improving depositional and paleoenvironmental interpretations. Sedimentary Geology, 349: 62-78.

Rotnicka, J., 2005. Ichnofabrics of the Upper Cretaceous fine-grained rocks from the Stołowe Mountains (Sudetes, SW Poland). Geological Quarterly, 49 (1): 15-30.

Saporta , M. de, 1887. Nouveaux documents relatifs aux organisms problematiques des anciens mers. Bulletin de la Société Géologique du France, 15: 286-302.

Sara, G., Pirro, M. de, 2011. Heart beat rate adaptations to varying salinity of two intertidal Meditteranean bivalves: The invasive Brachidontes pharaonis and the native Mytilaster minimum. Italian Journal of Zoology, 78: 193-197.

Schlirf, M., 2000. Upper Jurassic trace fossils from the Boulonnais (northern France). Geologica et Palaeontologica, 34: 145-213.

Schlirf, M., 2003. Palaeoecologic significance of Late Jurassic trace fossils from the Boulonnais, N France. Acta Geologica Polonica, 53: 123-142.

Schlirf, M., 2005. Revision and Description of Keuper (Middle Ladinian to Rhaetian) Invertebrate Trace Fossils from the Southern part of the Germanic Basin and Studies of Related Material. Disertation zur Erlangung des naturwissenschaftlichen Doktorgrades der Bayerischen Julius-Maximilians Universität Würzburg.

Schlotheim, E.T., von, 1813. Beiträge zur Naturgeschichte de Versteinerungen in geognostischer Hinsicht. Leonhard's Taschenbuch der Mineralogie, 7: 1-134.

Schmidt-Neto, H., Netto, R.G., Villegas-Martín, J., 2018 Bioerosion in shells from the Early Permian Rio Bonito Formation, Brazil: Taphonomic, paleobiological, and paleoecologica implications. Palaeogeography, Palaeoclimatology, Palaeoecology, 505: 256-264

Schneider, S., Niebuhr, B., Wilmsen, M., Vodrážka, R., 2011. Between the Alb and the Alps - The fauna of the Upper Cretaceous Sandbach Formation (Passau region, southeast Germany). Bulletin of Geosciences, 86: 785-816.

Schneider, S., Jäger, M., Kroh, A., Mitterer, A., Niebuhr, B., Vodrážka, R., Wilmsen, M., Wood, C.J., Zágoršek, K., 2013 Silicified sea life - Macrofauna and palaeoecology of the Neuburg Kieselerde Member (Cenomanian to Lower Turonian Wellheim Formation, Bavaria, southern Germany). Acta Geologica Polonica, 63: 555-610.

Scott, R.W., 1970. Paleoecology and paleontology of the Lower Cretaceous Kiowa Formation, Kansas. Article 52 (Cretaceous 1), The University of Kansas Publications. The University of Kansas Paleontological Institute, Lawrence, KS 66045.

Seeling, J., Bengtson, P., 1999. Cenomanian oysters from the Sergipe Basin, Brazil. Cretaceous Research, 20: 747-765.

Seeling, J., Bengtson, P., 2003. The bivalve Pinna cretacea (Schlotheim, 1813) from the Cretaceous of Brazil. Acta Palaeontologica Polonica, 48: 475-480.

Serres, M. de, 1840. Description de quelques mollusques fossiles nouveaux des terrains infra-jurassiques et de la craie compacte inférieure du midi de la France. Annales des Sciences Naturelles (Zoologie), 2 (XIV): 5-25.

Seilacher, A., 1967. Bathymetry of trace fossils. Marine Geology, 5 : 413-428.

Seilacher, A., 2007. Trace Fossil Analysis. Springer-Verlag, Berlin-Heilderberg-New York.
Singh, R.H., Rodríguez-Tovar, F.J., Ibotombi, S., 2008. Trace Fossils of the Upper Eocene-Lower Oligocene Transition of the Manipur, Indo-Myanmar Ranges (Northeast India). Turkish Journal of Earth Sciences, 17: 821-834.

Skoček, V., Valečka, J., 1983. Paleogeography of the Late Cretaceous Quadersandstein of Central Europe. Palaeogeography, Palaeoclimatology, Palaeoecology, 44: 71-92.

Stachacz, M., 2016. Ichnology of the Cambrian Ocieseki Sandstone Formation (Holy Cross Mountains, Poland). Annales Societatis Geologorum Poloniae, 86: 291-328.

Stanistreet, I.G., le Blanc Smith, G., Cadle, A.B., 1980. Trace fossils as sedimentological and palaeoenvironmental indices in the Ecca Group (Lower Permian) of the Transvaal. Transactions Geological Society of South Africa, 83: 333-344

Strzeboński, P., Uchman, A., 2015. The trace fossil Gyrophyllites in deep-sea siliclastic deposits of the Istebna Formation (Upper Cretaceous-Palaeocene) of the Carpathians: an example of biologically controlled distribution. Palaeogeography, Palaeoclimatology, Palaeoecology, 426: 260-274.

Swainson, W., 1840. A Treatise on Malacology; or the Natural Classification of Shells and Shell-fish. London, Logman.

Taylor, A.M., Goldring, R., 1993. Description and analysis of bioturbation and ichnofabric. Journal of the Geological Society, 150: 141-148.

Taylor, A., Goldring, R., Gowland, S., 2003. Analysis and application of ichnofabrics. Earth-Science Reviews, 60: 227-259.

Tiwari, R.O., Rajkonwar, C., Patel, S.J., 2013. Funalichnus bhubani isp. nov. from Bhuban Formation, Surma Group (Lower-Middle Miocene) of Aizawl, Mizoram, India. PLoS ONE, 8: e77839.

Tröger, K.-A., 2003. The Cretaceous of the Elbe Valley in Saxony (Germany) - a review. Carnets de Geologie/Notebooks on Geology (CG2003_A03_KAT)

Tröger, K.-A., 2017. Facies changes in the Cenomanian (Cretaceous) of the northwestern Elbe Valley near Dresden (Saxony, Germany). Acta Geologica Polonica, 67: 135-144.

Uchman, A., 1995. Taxonomy and palaeoecology of flysch trace fossils: the Marnoso-arenacea Formation and associated facies (Miocene, Northern Apennines, Italy). Beringeria, 15: 3-83.

Uchman, A., 1998. Taxonomy and ethology of flysch trace fossils revision of the Marian Książkiewicz collection and studies of complementary material. Annales Societatis Geologorum Poloniae, 68: 105-218.

Uchman, A., Gaździcki, A., 2006. New trace fossils from the La Meseta Formation (Eocene) of Seymour Island, Antarctica. Polish Polar Research, 27: 153-170.

Uchman, A., Krenmayr, H.G., 2004. Trace fossils, ichnofabrics and sedimentary facies in the shallow marine Lower Miocene Molasse of Upper Austria. Jahrbuch der Geologischen Bundesanstalt, 144: 223-251.

Uchman, A., Pervesler, P., 2007. Palaeobiological and palaeoenvironmental significance of the Pliocene trace fossil Dactyloidites peniculus. Acta Palaeontologica Polonica, 52: 799-808.

Uličný, D., 2001. Depositional systems and sequence stratigraphy of coarse-grained deltas in a shallow-marine, strike-slip setting the Bohemian Cretaceous Basin, Czech Republic. Sedimentology, 48: 599-628.

Uličný, D., Laurin, J., Čech, S., 2009. Controls on clastic sequence geometries in a shallow-marine, transtensional basin: the Bohemian Cretaceous Basin, Czech Republic. Sedimentology, 56 1077-1114.

Vakarelov, B.K., Ainsworth, R.B., MacEachern, J.A., 2012. Recognition of wave-dominated, tide-influenced shoreline systems in the rock record: microtidal shoreline model. Sedimentary Geology, 279: 23-41

Vialov, O.S., 1962. Problematica of the Beacon Sandstone at Beacon Heights, West Antarctica. New Zealand Journal of Geology and Geophysics, 5: 718-732.

Vlahović, I., Mikša, G., Mrinjek, E., Hasiotis, S.T., Velić, I., Tišljar, J., Matičec, D., 2011. Response of tracemakers to temporary 
platform drowning: Lower Cenomanian of southern Istria (western Croatia). Palaios, 26: 567-577.

Voigt, S., Wagreich, M., Surlyk, F., Walaszczyk, I., Uličný, D., Čech, S., Voigt, T., Wiese, F., Wilmsen, M., Niebuhr, B., Reich, M., Funk, H., Michalík, J., Jagt, J.W.M., Felder, P. J., Schulp, A.S., 2008. Chapter 15. Cretaceous. In: The Geology of Central Europe (ed. T. McCann), 2: 923-997. London, Geological Society.

Walczak-Augustyniak, M., Wroński, J., 1981. Szczegółowa mapa geologiczna Sudetów w skali 1:25 000, arkusz Domaszków (in Polish). Instytut Geologiczny, Wyd. Geol., Warszawa.

Wesolowski, L.J.N., Buatois, L.A., Mángano, M.G., Ponce, J.J., Carmona, N.B., 2018. Trace fossils, sedimentary facies and parasequence architecture from the Lower Cretaceous Mulichinco Formation of Argentina: the role of fair-weather waves in shoreface deposits. Sedimentary Geology, 367: 146-163.

Wetzel, A., Bromley, R.G., 1994. Phycosiphon incertum revisited: Anconichnus horizontalis is its junior subjective synonym. Journal of Paleontology, 68: 1396-1402.

Wetzel, A., Carmona, N.B., Ponce, J.J., 2020. Gyrochorte "highways" and their environmental significance in shallow-marine sediments. Acta Palaeontologica Polonica, 65: 209-218.

Wilmsen, M., Niebuhr, B., 2014a. The rosetted trace fossil Dactyloidites ottoi (Geinitz, 1849) from the Cenomanian (Upper Cretaceous) of Saxony and Bavaria (Germany): ichnotaxonomic remarks and palaeoenvironmental implications. Paläontologische Zeitschrift, 88: 123-138.
Wilmsen, M., Niebuhr, B., 2014b. Stratigraphy and depositional setting of the Cretaceous in Saxony (Elbtal Group, Cenomanian-Lower Turonian). Geologica Saxonica, 60: 347-369.

Wilmsen, M., Niebuhr, B., Wood, C.J., Zawischa, D., 2007. Fauna and palaeoecology of the Middle Cenomanian Praeactinocamax primus Event at the type locality, Wunstorf quarry, northern Germany. Cretaceous Research, 28: 428-460.

Wilson, M.A., 2007. Macroborings and the evolution of marine bioerosion. In: Trace Fossils, Concepts, Problems, Prospects (ed. W. Miller III): 356-381.

Wisshak, M., Knaust, D., Bertling, M., 2019. Paleoecology and paleontology of the Lower Cretaceous Kiowa Formation, Kansas. Article 52 (Cretaceous 1), The University of Kansas Publications. The University of Kansas Paleontological Institute, Lawrence Facies, 65: 24.

Wojewoda, J., 1997. Upper Cretaceous littoral-to-shelf succession in the Intrasudetic Basin and Nysa Trough, Sudety Mts. In: Obszary Źródłowe: Zapis w osadach (ed. J. Wojewoda): 81-96. WIND, Wrocław.

Woodward, S., 1830. A synoptic table of British organic remains, i-xiii, 1-50. London, Longman \& John Stacy.

Wroński, J, 1982. Objaśnienia do szczegółowej mapy geologicznej Sudetów w skali 1:25 000, Arkusz Domaszków (in Polish). Instytut Geologiczny, Wyd. Geol., Warszawa.

Wroński, J., Cwojdziński, S., 1984. Objaśnienia do szczegółowej mapy geologicznej Sudetów w skali 1:25 000, Arkusz Bystrzyca Kłodzka (in Polish). Instytut Geologiczny, Wyd. Geol., Warszawa. 